\title{
Review
}

Medical Principles

and Practice

Med Princ Pract 2012;21:404-428

DOI: $\underline{10.1159 / 000334488}$
Received: January 30, 2011

Accepted: October 5, 2011

Published online: January 11, 2012

\section{Interactions between Herbs and Conventional Drugs: Overview of the Clinical Data}

\author{
Angelo A. Izzo \\ Department of Experimental Pharmacology, Federico II University of Naples, Naples, Italy
}

\section{Key Words}

Complementary medicine $\cdot$ Cytochrome P · Dietary

supplements $\cdot$ Drug interaction $\cdot$ Herbal medicine $\cdot$

P-glycoprotein - Traditional Chinese medicine $\cdot$ Safety of

herbal products $\cdot$ St. John's wort

\begin{abstract}
This article provides an overview of the clinical evidence of interactions between herbal and conventional medicines. Herbs involved in drug interactions - or that have been evaluated in pharmacokinetic trials - are discussed in this review. While many of the interactions reported are of limited clinical significance and many herbal products (e.g. black cohosh, saw palmetto, echinacea, hawthorn and valerian) seem to expose patients to minor risk under conventional pharmacotherapy, a few herbs, notably St. John's wort, may provoke adverse events sufficiently serious to endanger the patients' health. Healthcare professionals should remain vigilant for potential interactions between herbal medicines and prescribed drugs, especially when drugs with a narrow therapeutic index are used.

Copyright $\odot 2012$ S. Karger AG, Basel
\end{abstract}

\section{Introduction}

According to the World Health Organisation, herbal medicines are defined as 'finished, labelled medicinal products that contain as active ingredients aerial or underground parts of plants, or other plant material, or combinations thereof, whether in the crude state or as plant preparations. Plant material includes juices, gums, fatty oils, essential oils, and any other substances of this nature. Herbal medicines may contain excipients in addition to the active ingredients. Medicines containing plant material combined with chemically defined active substances, including chemically defined, isolated constituents of plants, are not considered to be herbal medicines' [1]. Thus, herbal medicines contain a combination of pharmacologically active plant constituents that are claimed to work synergistically to produce an effect greater than the sum of the effects of the single constituents [2-5]. There is a general belief by the public that herbal medicines are safe because they are natural. However, this is a hazardous oversimplification. Many different side effects to herbs have been reported and recently reviewed $[6,7]$, including adverse events caused by herb-todrug interactions [6-8]. Since all herbal medicines are mixtures of more than one active ingredient, such combinations of many substances obviously increase the like-

Angelo A. Izzo

Department of Experimental Pharmacology, Federico II University of Naples via Domenico Montesano 49

IT-80131 Naples (Italy)

Tel. +39081678 439, E-Mail aaizzo@ unina.it 
lihood of interactions taking place. Hence, theoretically, the likelihood of herb-to-drug interactions is higher than drug-to-drug interactions, if only because synthetic drugs usually contain single chemical entities.

The aim of this article is to provide an overview of the clinical data regarding the interactions between herbal remedies and prescribed drugs. Detailed considerations on the mechanisms and molecular explanations of the clinical observations of herb-to-drug interactions can be found elsewhere [9-11]. The herbal remedies involved in clinical herb-to-drug interactions are given in table 1, which also reports the level of evidence for each interaction. The ultimate goal of this article is to raise the awareness of pharmacists and physicians regarding this topic and thus protect the health of consumers.

\section{Mechanisms of Herb-to-Drug Interactions: General Considerations}

Herb-to-drug interactions are based on the same pharmacokinetic (changes of plasma drug concentration) and pharmacodynamic (drugs interacting at receptors on target organs) principles as drug-to-drug interactions.

The pharmacokinetic interactions that have been identified so far all point towards the fact that a number of herbs, most notably St. John's wort, can affect the blood concentration of different conventional medicines that are metabolized by cytochrome P450 (CYP, the most important phase I drug-metabolizing enzyme system) and/ or are transported by P-glycoprotein (a glycoprotein which influences drug absorption and elimination by limiting the cellular transport from the intestinal lumen into epithelial cells and by enhancing the excretion of drugs from hepatocytes and renal tubules into the adjacent luminal space). Polymorphisms in the genes for CYP enzymes and P-glycoprotein may influence the interactions mediated through these pathways [12]. Probe drugs used in pharmacokinetic trials include midazolam, alprazolam, nifedipine (CYP3A4), chlorzoxazone (CYP2E1), debrisoquine, dextromethorphan (CYP2D6), tolbutamide, diclofenac and flurbiprofen (CYP2C9), caffeine, tizanidine (CYP1A2) and omeprazole (CYP2C19). Fexofenadine, digoxin and talinolol have been extensively used in pharmacokinetic trials as P-glycoprotein substrates.

Pharmacodynamic interactions have been less studied but may be additive (or synergetic), i.e. the herbal medicines potentiate the pharmacological/toxicological action of synthetic drugs, or antagonistic, i.e. the herbal medicines reduce the efficacy of synthetic drugs. Warfarin interactions are a classical example of pharmacodynamic interactions. Theoretically, increased anticoagulant effects could be expected when warfarin is combined with coumarin-containing herbs (some plant coumarins exert anticoagulant effects) or with antiplatelet herbs. Conversely, vitamin K-containing herbs can antagonize the effect of warfarin (the action of warfarin is due to its ability to antagonize the cofactor function of vitamin K).

Comprehensive review articles specifically highlighting the mechanisms of herb-to-drug interactions, including evidence of herbs that can modulate CYP or P-glycoprotein have recently been published [9-12].

\section{Level of Clinical Evidence}

In this article, clinical evidence has been categorized into the following levels:

Level 1: incomplete case report, presence of other explanatory factors for the adverse reaction, adverse event unlikely from a pharmacological viewpoint.

Level 2: case report providing some evidence for an interaction, other causes not fully excluded (e.g. interactions indicated as 'probable' or 'possible' by the Naranjo probability scale).

Level 3: well-documented case report; multiple case reports, case series.

Level 4: pharmacokinetic trials in patients or healthy volunteers.

Level 5: interaction highlighted by case report(s) and confirmed by clinical pharmacokinetic trials.

Level of evidence 'not applicable': adverse event highlighted by case report(s) and not confirmed by clinical trials, contradictory data from different clinical trials.

\section{Clinical Interactions between Herbs and Conventional Drugs}

An overview of the clinical data regarding herb-todrug interactions for a number of herbal remedies known to interact with conventional medicines is reported below.

\section{Aloe vera}

Aloe vera (Fam. Liliaceae) is used in western countries as a laxative (A. vera latex, which contains anthraquinones) and for dermatologic conditions ( $A$. vera gel, containing mainly mucilages) $[2,4]$. In traditional Chinese 
medicine, $A$. vera is mainly employed for inflammatory conditions, diabetes and hyperlipidaemia. Blood loss during surgery as a result of a possible interaction between $A$. vera and the anaesthetic sevoflurane has been reported [13]. An additive effect on platelet function has been hypothesized but not proven since both sevoflurane and $A$. vera ingredients may inhibit platelet aggregation.

\section{Black Cohosh (Cimicifuga racemosa)}

Black cohosh (Cimicifuga racemosa rhizome and roots, Fam. Ranunculaceae), mostly used to treat symptoms of menopause $[2,3]$, has been associated with serious safety concerns, such as hepatotoxicity, which urgently require further investigation $[3,4]$.

The effect of black cohosh extract on the activity of human CYP enzymes as well as on P-glycoprotein has been evaluated in a number of clinical trials [14-17] using different probe drugs, including caffeine, midazolam, chlorzoxazone, debrisoquin and digoxin. The results suggest that black cohosh is unlikely to affect the pharmacokinetics of conventional drugs that are metabolized by CYP1A2, CYP3A4, CYP2E1 and CYP2D6 or are substrates of P-glycoprotein. In addition, seven different brands of commercial black cohosh products were found not to affect human CYP using an in vitro liver microsomal technique [18]. On the whole, black cohosh seems to pose only minor risks in patients undergoing conventional pharmacotherapy.

\section{Cat's Claw (Uncaria tomentosa)}

Cat's claw (Uncaria tomentosa, Fam. Rubiaceae) is a medicinal plant from the Amazon rainforest. Due to its immunostimulant and antiviral effects, it has been used for conditions, such as rheumatoid arthritis and AIDS [2]. Cat's claw has been shown to increase the plasma concentration of the protease inhibitors atazanavir, ritonavir and saquinavir [19]. In vitro, cat's claw has been shown to inhibit CYP3A4, which is responsible of the metabolism of the protease inhibitors. However, no human data on the possible modulation of CYP enzymes by cats' claw have been provided to date.

\section{Chamomile (Matricaria recutita)}

Chamomile, consisting of fresh or dried flower heads of Matricaria recutita (Fam. Asteraceae), is used both externally (for skin and mucous membrane inflammations) and internally (for the treatment of gastrointestinal spasms and inflammatory disease of the gastrointestinal tract) $[4,5]$. Chamomile contains coumarins, a large class of over 1,300 natural compounds. Some, but definitely not all, coumarin compounds may exert an anticoagulant effect [20]. A case of rectus sheath and retroperitoneal haematomas was reported in a patient under warfarin therapy [21]. It was believed, but not proven, that the coumarin constituents of chamomile may have worked synergistically or additively with warfarin, resulting in overanticoagulation.

\section{Cranberry (Vaccinium macrocarpon)}

Cranberry is the American name of the fruit of Vaccinium macrocarpon (Fam. Ericaceae); it has been used for decades to prevent urinary tract infections $[3,4]$, generally in the form of an encapsuled standardized extract, a dilute juice or a dried-juice capsule [4].

On the basis of multiple published cases (including 2 cases of fatal interaction) reporting increased international normalized ratio (INR) and haemorrhage [21-31], serious concerns have been raised regarding a possible interaction with the anticoagulant warfarin. However, these warnings may possibly be attributed to misleading conclusions [32].

With the exception of one study, which showed that capsules containing concentrated cranberry juice increased the area under the INR-time curve of warfarin by $30 \%$ [33], a number of clinical trials have consistently shown that cranberry juice, even administered at high doses, did not cause any clinically relevant changes in warfarin pharmacokinetics and pharmacodynamics [34-38]. Clinical evidence indicates the lack of interaction between cranberry juice and some CYP isoenzymes, e.g. CYP2C9, CYP1A2 and CYP3A4 [36-38] necessary for warfarin metabolism [39]. Finally, a clinical trial found that pomelo juice, but not cranberry juice, affected the pharmacokinetics of cyclosporine (CYP3A4 and P-glycoprotein substrate) in humans [40].

\section{Danshen (Salvia miltiorrhiza)}

Danshen, also known as Chinese salvia or red salvia, are preparations derived from the roots and rhizome of Salvia miltiorrhiza (Fam. Lamiaceae). Danshen is widely used in traditional Chinese medicine to prevent and treat cardiovascular conditions, such as acute ischemic stroke and myocardial infarction [2-4]. Danshen can affect haemostasis in several ways, including inhibition of platelet aggregation. Case reports have highlighted the possibility of interactions between warfarin and danshen, resulting in an increased anticoagulant effect [41-44]. A pharmacokinetic mechanism seems unlikely since danshen has been shown to induce intestinal CYP3A4 in 14 healthy volunteers [45]. 
Dong Quai (Angelica sinensis)

Angelica sinensis (Fam. Apiaceae), commonly known as 'dong quai', is one of the most popular traditional Chinese medicines [4]. Preparations from its roots are used mainly for dysmenorrhoea, amonorrhoea or excessive menstrual flow. The actions of dong quai are said to be due to the presence of a number of chemical constituents, including coumarins [4], which may have anticoagulant actions [20]. Two well-documented case reports suggest overanticoagulation following co-administration of warfarin and dong quai $[46,47]$.

\section{Echinacea (Echinacea spp.)}

Echinacea preparations derive from underground as well as aerial parts of several species of Echinacea (Fam. Asteraceae), e.g. E. angustifolia, E. pallida and E. purpurea [4]. Due to its immunostimulant properties, echinacea is widely used for the prevention and treatment of common infections, such as respiratory tract infections [2-4].

Echinacea seems to pose no serious risk for drug interactions in humans. No verifiable case reports of drug-toherb interactions with any echinacea product have been published to date. Echinacea did not change the pharmacokinetics of digoxin, a P-glycoprotein substrate [48] nor did it alter the pharmacokinetics of chlorzoxazone (CYP2E1 probe) [17], debrisoquine (CYP2D6 probe) [17, 49], dextromethorphan (CYP2D6 probe) [50] or tolbutamide (CYP2C9 probe) [50]. Some studies have found that echinacea affects caffeine (CYP1A2 probe) and midazolam (CYP3A4 probe) pharmacokinetics; however, this has not been confirmed by other clinical trials $[17,49]$.

Finally, a recent clinical trial showed that E. purpurea root extract did not affect the overall darunavir or ritonavir (a combination of protease inhibitors) pharmacokinetics in HIV patients [51]. Protease inhibitors are mainly metabolized by CYP3A4 and are P-glycoprotein substrates.

\section{Eleuthero (Eleutherococcus senticosus)}

Eleuthero, also named 'Siberian ginseng', belongs to the same family (Araliaceae) as Asian ginseng (Panax ginseng). Like Asian ginseng, eleuthero is promoted as a 'tonic for invigoration and fortification in times of fatigue and debility or declining capacity for work and concentration, also during convalescence' [5].

Eleuthero, at generally recommended over-the-counter doses, is unlikely to alter the disposition of co-administered medications primarily metabolized by CYP2D6 or CYP3A4 [52].
Increased levels of digoxin have been associated with ingestion of eleuthero [53]. In this case, the patient was asymptomatic for digoxin toxicity despite high plasma levels of the cardiotonic drug. Since eleuthero contains glycosides with structural similarities to digoxin that interfere with digoxin assays, this is not a real clinical herbto-drug interaction, but rather represents an artefact of digoxin assays.

\section{Garlic (Allium sativum)}

Garlic (Allium sativum L., Fam. Alliaceae) is used in modern phytotherapy to treat hypercholesterolaemia and prevent arteriosclerosis although the clinical evidence is far from compelling $[2,3]$. Garlic preparations include garlic powder standardized to contain $1.3 \%$ alliin and $0.6 \%$ allicin, garlic aged extract, which does not contain allicin but is high in water soluble phytochemicals, such as diallyl sulphides and garlic oil (i.e. essential oil obtained from the distillation of the cloves) [4].

Two garlic preparations, namely garlic oil and garlic powder, have been evaluated for their potential to affect CYP enzymes in clinical trials. The results suggest that garlic oil may selectively inhibit CYP2E1, but not other CYP isoforms (such as CYP1A2, CYP3A4 or CYP2D6) and that garlic powder has no effect on CYP3A4 [54-58]. Recently, it has been shown that a 21-day garlic treatment (aged garlic extract) induces intestinal expression of P-glycoprotein without affecting intestinal or hepatic CYP34A in humans [59].

The most thoroughly studied garlic interactions with conventional drugs include interactions with the anticoagulant warfarin, which, in any case, have not been confirmed by controlled clinical trials or antiretroviral drugs (see details in table 1) [60-67]. Other irrelevant and/or poorly documented interactions include changes in paracetamol pharmacokinetics [68] and hypoglycaemia when combined with the antidiabetic drug chlorpropamide [69].

\section{Ginger (Zingiber officinale)}

Ginger (rhizome of Zingiber officinale, Fam. Zingiberaceae) preparations are effective in attenuating nausea and vomiting during pregnancy and during the post-operative period [2-4]. They showed considerable antiplatelet effects in preclinical studies [4] and this might explain the elevated INR in a patient taking it concomitantly with the anticoagulant phenprocoumon [70]. However, such an interaction has not been confirmed by a clinical trial [71]. 


\section{Ginkgo (Ginkgo biloba)}

Extracts from the leaves of the ginkgo tree (Ginkgo biloba, Fam. Ginkgoaceae) are used for the treatment of cognitive impairments, dementia, intermittent claudication and tinnitus [2-5]. The effect of ginkgo on various CYP isoforms as well as on P-glycoprotein has been investigated in a number of clinical trials by using different probe drugs, such as alprazolam, midazolam, diazepam, nifedipine (CYP3A4), caffeine (CYP1A2), chlorzoxazone (CYP2E1), debrisoquine (CYP2D6), tolbutamide, diclofenac, flurbiprofen (CYP2C), omeprazole, voriconazole (CYP2C19), fexofenadine, digoxin and talinolol (P-glycoprotein substrates) $[55,56,72-82]$. Given the heterogeneity of the results, firm conclusions cannot be drawn. Nevertheless, the results seem to suggest minor or no effect of ginkgo on the various CYP isoforms or on P-glycoprotein.

It is often mentioned that ginkgo can interact with anticoagulant drugs [2-4]. However, clinical evidence refuted this notion since this herbal product has been shown not to affect blood coagulation or platelet function in humans [83]. Clinical trials have also shown that ginkgo has no additive effect with aspirin on platelet aggregation [84], does not change the antiplatelet activity of clopidogrel and cilostazol [85] and has no effect on warfarin INR and platelet aggregation $[71,86]$. In light of these recent controlled clinical data, causality and mechanisms advanced in previous case reports, in which ginkgo was suspected to cause spontaneous hyphaema when associated with aspirin [87], intracerebral haemorrhage when associated with warfarin [88] and intracerebral mass bleeding when associated with ibuprofen [89], should be re-examined.

Finally, single cases suggest that ginkgo may cause priapism when combined with the antipsychotic drug risperidone [90], coma when combined with the atypical antidepressant trazodone [91], fatal seizure when combined with the anticonvulsant drugs valproic acid and phenytoin [92] and virological failure when combined with efavirenz, a non-nucleoside reverse transcriptase inhibitor [93].

It should be noted that, in clinical trials, EGb 761, a well-defined extract of Ginkgo biloba leaves, standardized to contain $24 \%$ flavone glycosides and $6 \%$ terpene lactones, has been used. EGb 761 has generally not been implicated in case reports [83].

\section{Ginseng (Korean Ginseng, Panax ginseng)}

Preparations of Asian ginseng, obtained from the roots of Panax ginseng (Fam. Araliaceae), are used to re- duce susceptibility to illness, promote health and longevity, restore male sexual function and aid convalescence [ 4 , 5]. Pure ginsenosides can inhibit platelet aggregation in vitro [4]. However, clinical studies have consistently demonstrated that ginseng extracts have had no significant effect on platelet function in humans [94] and did not change the pharmacokinetics or pharmacodynamics of warfarin [95-97]. Surprisingly, a decreased anticoagulant effect has been reported in a patient taking both ginseng and warfarin [98].

Case reports suggest potentially serious interactions when ginseng is used with the antidepressant phenelzine and the anticancer drug imatinib [99-101] (see table 1 for details). Finally, the clinical results consistently showed that ginseng does not affect CYP enzymes although a slight inhibition of CYP2D6 has been observed $[55,56]$.

\section{Ginseng (American Ginseng, Panax quinquefolius)}

Panax quinquefolius (Fam. Araliaceae), commonly known as 'American ginseng', is a herbaceous perennial herb native to North America [4,5]. A clinical study showed that American ginseng reduced the anticoagulant effect of warfarin in healthy volunteers [102] (see table 1 for further details). On the other hand, two clinical trials have recently shown that American ginseng did not affect the pharmacokinetics of the antiretroviral drugs indinavir and zidovudine $[103,104]$.

\section{Goldenseal (Hydrastis canadensis)}

Goldenseal (Hydrastis canadensis, Fam. Ranunculaceae) has a history of folk medicine use in the treatment of gastrointestinal disturbances, urinary disorders, skin ailments and various infections [2, 4]. A clinical trial showed that goldenseal did not change the disposition of digoxin, suggesting that this herb has no effect on P-glycoprotein [105]. Although one study did not yield the same conclusions [106], convincing clinical evidence suggests that adverse herb-to-drug interactions may result with concomitant ingestion of goldenseal and drugs that are metabolized by CYP3A4 or CYP2D6 [14, 17, 107, 108]. Therefore, although no clinical case report of herb-todrug interaction has been published to date, goldenseal should be not administered concomitantly with drugs that are metabolized by CYP3A4 or by CYP2D6.

\section{Green Tea (Camellia sinensis)}

Green tea (Camellia sinensis leaves, Fam. Theaceae) is used both as a beverage and as a herbal drug [4]. Possibly due to its vitamin $\mathrm{K}$ content, green tea might reduce the anticoagulant effect of warfarin [109]. Furthermore, 
green tea has been shown to reduce acid folic and the plasma level of statins through a mechanism that remains to be clarified $[110,111]$. Lastly, green tea has minor effects on human CYP3A4 $[112,113]$.

\section{Kava (Piper methysticum)}

Preparation from the rhizome and roots of Piper methysticum (Fam. Piperaceae) are used for the treatment of anxiety, and the available evidence suggests that kava extracts are superior to placebo for treating patients with anxiety disorders [2-4]. Unfortunately, in the UK and various other European countries, the sale of kava is currently prohibited due to reports of potential hepatotoxicity [4].

In vitro, kavalactones, the active ingredients of kava, have been shown to be potent inhibitors of several enzymes of the CYP450 system [114]. However, clinical trials have shown that, at therapeutic doses, kava inhibits CYP2E1 but not other CYP isoforms, such as CYP3A4, CYP2D6 or CYP1A2. Kava does not affect P-glycoprotein $[14,17,105,107,108]$.

Some possible pharmacodynamic interactions, highlighted by single case reports have been postulated to occur when combining kava with benzodiazepines, antiParkinson or antidepressant drugs (see table 1 for further details) [115-117].

\section{Licorice (Glycyrrhiza glabra)}

The roots and rhizomes of Glycyrrhiza glabra (Fam. Fabaceae) are mainly used for the treatment of peptic ulcer and catarrhs of the upper respiratory tract [2-5]. A preliminary report, published in abstract form only, showed that the ingestion of aqueous licorice extract for 7 days did not significantly alter the pharmacokinetics of midazolam, a CYP3A4 substrate [118]. However, both glycyrrhizin and glycyrrhetic acid (i.e. chemical components of licorice) have recently been shown to induce CYP3A4 in humans $[119,120]$. In the absence of definitive data for standardized licorice extracts, it is suggested that this herbal remedy should be used with caution when taken concomitantly with other drugs that interact with CYP3A4.

There is some indirect evidence that licorice may affect the pharmacokinetics of prednisolone. Glycyrrhizin is known to increase the plasma prednisolone concentration in humans and is one of the ingredients of three major traditional Chinese formulations, namely Sho-saikoTo, Saiboku-to, and Sairei-To, which all affected prednisolone pharmacokinetics in healthy volunteers [121, 122].

Herb-Drug Interactions

\section{Milk Thistle (Silybum marianum)}

Phytotherapeutic milk thistle preparations are obtained from Silybum marianum (Fam. Asteraceae) and are used to treat liver diseases [2-4]. S. marianum extracts seem to have minor effects on the pharmacokinetics of drugs metabolized by CYP enzymes or transported by P-glycoprotein. With the exception of one study [123], several clinical trials have reliably shown that $S$. marianum extracts did not affect the pharmacokinetics of a number of drugs metabolized by various CYP isoforms (e.g. CYP1A2, CYP2D6, CYP2E1 and CYP3A4) and/or transported by P-glycoprotein [15, 16, 124-130]. Overall, milk thistle seems to pose no risk for drug interactions in humans.

\section{Peppermint (Mentha piperita)}

Peppermint leaf and oil from Mentha piperita (Fam. Labiateae) have a long history of use in digestive disorders $[3,4]$. Recent evidence suggests that enteric-coated peppermint oil may be effective in relieving some of the symptoms of irritable bowel syndrome [3]. Some clinical data suggest that peppermint might increase the levels of drugs metabolized by CYP3A4, such as felodipine [131].

\section{Red Yeast Rice}

Red yeast rice is produced by fermentation of washed and cooked rice using the fungus Monascus purpureus and is used to lower blood cholesterol [3, 4]. Red yeast rice has been suspected to cause rhabdomyolysis in a a stable renal-transplant patient under cyclosporine treatment [132] (see table 1 for further details). It should be noted that red yeast rice may cause myopathy even when administered alone [133].

\section{Saw Palmetto (Serenoa repens)}

Serenoa repens (Fam. Arecaceae) preparations are well tolerated by most users and are not associated with serious adverse events [2-4]. No evidence for drug interactions with saw palmetto has been published. Two clinical studies demonstrated that saw palmetto had no significant effect on CYP1A2, CYP2D6, CYP2E1 or CYP3A4 in healthy volunteers $[50,134]$. Extracts from $S$. repens berries are the most widely used herbal preparations for the treatment of benign prostatic hyperplasia $[2-5,200]$. Saw palmetto, pumpkin and vitamin $\mathrm{E}$ are ingredients of curbicin, a herbal formulation used to relieve symptoms associated with benign prostatic hyperplasia. Two cases of increased INR were reported after co-administration of curbicin and warfarin [135]; the INR normalized after discontinuation of curbicin. No anticoagulant effect has

Med Princ Pract 2012;21:404-428 
been found in the literature associated with both saw palmetto and pumpkin. However, vitamin $\mathrm{E}$ has been shown to antagonize the effect of vitamin $\mathrm{K}$ and may lead to an increased risk of bleeding, particularly in patients taking oral anticoagulants [136]. The currently available evidence suggests that saw palmetto is unlikely to pose serious health threats to patients combining it with conventional drugs.

\section{Schisandra chinensis}

Schisandra chinensis (Wuweizi, Fam. Schizandraceae) is used in modern Chinese medicine as an adaptogenic drug [137]. A clinical trial showed that the herb increased the area under the curve and $\mathrm{T}_{\max }$ of tanilolol, a P-glycoprotein substrate [82]. Thus, patients receiving S. chinensis might require dose adjustments when treated with drugs primarily transported by P-glycoprotein.

\section{Schisandra sphenanthera}

Schisandra sphenanthera (Nan-Wuweizi) is widely used to treat viral and drug-induced hepatitis in China [137]. Two clinical trials showed that extracts obtained from S. sphenanthera increased the oral bioavailability of the immunosuppressive drug tacrolimus, which is metabolized by CYP3A4 and P-glycoprotein [138, 139]. A further study showed that $S$. sphenanthera increased the oral bioavailability of midazolam (CYP3A4 substrate) [140]. Overall, S. sphenanthera preparations should not be co-administered with CYP3A4-metabolized drugs.

\section{Soy (Glycine max)}

Soy beans, obtained from Glycine max (Fam. Fabaceae), are very rich in phytoestrogens, i.e. non-steroidal plant-derived compounds possessing a weak oestrogenic activity. Soy phyto-oestrogens are claimed to exert beneficial effects in the treatment of menopausal symptoms and prevention of heart disease and cancer $[2,4]$. Decreased INR has been reported in a patient under warfarin therapy [141]. On the other hand, a clinical study showed that a 14-day treatment with soy extract did not significantly influence the pharmacokinetics of losartan and its active metabolite E-3174 in 18 healthy Chinese female volunteers [142].

\section{St. John's Wort (Hypericum perforatum)}

Hypericum perforatum L. (St. John's wort) extracts are widely used as a safe alternative to conventional antidepressant drugs for mild to moderate forms of depressive disorders $[2,5]$. The herb contains numerous compounds with documented biological activity, including the naph- thodianthrone hypericin, a broad range of flavonoids, and the phloroglucinol hyperforin, which inhibits the re-uptake of several brain neurotransmitters, including 5-hydroxytryptamine (5-HT, serotonin) [4].

The possible interactions with conventional medicines are the most important risk associated with the intake of $H$. perforatum extracts [143]. St. John's wort represents the herbal product that is most involved in herbto-drug interactions. Clinical evidence suggests that St. John's wort may cause both pharmacokinetic and pharmacodynamic interactions. Using well-established probe drugs, a great number of clinical trials have consistently shown that St. John's wort induced P-glycoprotein as well as CYP3A4, CYP2E1 and CYP2C19, with no effect on CYP1A2, CYP2D6 or CYP2C9 [144-157]. Induction of $\mathrm{CYP}$ enzymes and $\mathrm{P}$-glycoprotein is caused by hyperforin via activation of the pregnane $\mathrm{X}$ receptor [158-161].

Pharmacodynamic interactions may occur when St. John's wort is given together with drugs that enhance 5-HT signaling in the brain (e.g. 5-HT re-uptake inhibitors, 5-HT ligands). St. John's wort has been shown to clinically interact with a number of conventional drugs mostly via these pharmacokinetic and/or pharmacodynamic mechanisms; such interactions take place with immunosuppressants (cyclosporine, tacrolimus, prednisone), hormones (oral pill, tibolone), cardiovascular drugs (the anticoagulants warfarin and phenprocoumon, the cardiac inotropic drug digoxin, the antilipidaemic drugs simvastatin, rosuvastatin and atorvastatin, the calcium blockers nifedipine and verapamil, the $\beta_{1}$-adrenoreceptor blocker talinolol, the anti-anginal drug ivabradine), antiretroviral drugs (indinavir, nevirapine), anticancer drugs (irinotecan, imatinib), drugs acting on the CNS (anaesthetics, the anxyolityc drugs alprazolam, midazolam, quazepam and buspirone, the antidepressants sertraline, nefazodone, paroxetine, venlafaxine and amitriptyline, the anti-epileptic drugs mephenytoin, drugs for addicted patients, such as methadone and bupropion, the centrally acting muscle relaxant chlorzoxazone, the antitussive drug dextromethorphan), anti-ulcer medications (omeprazole), antidiarrhoeal drugs (loperamide), drugs acting on the respiratory system (theophylline, fexofenadine), antifungal drugs (voriconazole) and antimigraine medicines (eletriptan) [55, 56, 143, 146-151, 154, 162-221] (see table 1 for further details).

Well-documented and clinically relevant interactions include: (1) reduced blood cyclosporine concentration associated in some cases to rejection episodes; (2) reduced efficacy of the oral pill, resulting in unwanted pregnancy; (3) reduced plasma concentration of antiretroviral (e.g. 
indinavir, nevirapine) and anticancer drugs (e.g. imatinib, irinotecan).

\section{Valerian (Valeriana officinalis)}

Valerian (Valeriana officinalis, Fam. Valeraniaceae) root preparations are widely available in a variety of commercial preparations as a sleep aid. Clinical evidence supports the notion that valerian is a safe herb associated with only rare adverse events [2-4]. Valerian has no impact on a number of CYP isoenzymes, including CYP3A4, CYP2D6, CYP2E1, CYP1A2 [14].

Valerian might theoretically potentiate the effect of CNS depressants. Hand tremor, dizziness, throbbing and muscular fatigue have been reported in a patient selfmedicated with valerian and passion flower (Passiflora incarnata) while on lorazepam treatment. Also, a brief episode of acute delirium has been reported in a patient taking the antidiarrhoeal drug loperamide in combination with St. John's wort and valerian [223].

\section{Other Herbs Involved in Drug Interactions}

Other herbal products that have been implicated in drug interactions include betel nut (Areca catechu, used for the preparation of a relaxing/refreshing beverage) [224], chlorella (Chlorella pyrenoidosa), a unicellular fresh water green alga used mainly as a potential source of food and energy and also believed to have some therapeutic benefits [225], boldo (Peumus boldus) used as a choleretic/cholagogue drug [226], fenugreek (Trigonella foenum-graecum), mostly used for the treatment of hypercholesterolaemia and diabetes mellitus [226], evening primrose oil (Oenothera biennis), mostly used in dermatology as well as for the treatment of rheumatoid arthritis [227], maitake (Grifolia frondosa), an edible mushroom with potential anticancer benefits [228], mistletoe (Viscum album) used as a palliative therapy for malignant tumors [229], prickly pear cactus (Opuntia polyacantha), traditionally used in Mexico for the treatment of diabetes [230], goji (Lycium barbarum), used in traditional Chinese medicine in cases of loss of energy, diabetes and liver disorders) [231, 232], and hibiscus (Hybiscus sabdariffa), used in folk medicine for the treatment of hypertension $[233,234]$. Details of such interactions are reported in table 1 .

Gums, mucilages, pectins or fibers contained in several medicinal plants have the ability to bind, trap and form viscous matrices with concurrently administered drugs. Hence, they may reduce their absorption. For ex- ample, a decrease in the absorption of lovastatin (associated to increased LDL levels) was observed in patients who took the statin concomitantly with pectin or oat bran [235]. Clinical data have shown that plant products, such as gum guar (from Cyamopsis tetragonolobus), acacia gum (from Acacia senegal), or guggulipid (a standardized neutral fraction extract of gum guggul, an oleoresin obtained from Commiphora mukul) may reduce the absorption of drugs, such as metformin [236], amoxicillin [237], propranolol [238], and digoxin [239]. A case of a decreased INR, suggestive of decreased anticoagulant effect, has been reported in a 57-year old man who began treating himself with an aqueous extract of the boiled roots of Commiphora molmol with his usual warfarin [240]. C. molmol, one of the primary trees used in the production of myrrh, is traditionally used for the treatment of diabetes mellitus.

Finally, clinical studies have shown that hawthorn (Crategus oxyacantha), used for the treatment of congestive heart failure), had no effect on the pharmacokinetics of digoxin (P-glycoprotein substrate) [241] and Citrus aurantium subspecies amara (bitter orange peel) used for dyspeptic ailments, had no effect on various CYP isoforms, namely CYP3A4, CYP1A2, CYP2E1, and CYP2D6 [49].

\section{Patient Characteristics}

Characteristics of the patient, such as age, frailty, infrequent genotypes, ethnicity, gender, and comorbidity [242] should be taken into account when considering herb-to-drug interactions.

It is well known that polymorphisms in the genes for drug-metabolizing enzymes or transporters may influence herb-to-drug interactions [12]. For example, ginkgo can induce omeprazole hydroxylation in a CYP2C19 genotype-dependent manner (i.e. the effect has been shown to be more pronounced in poor metabolizers than in extensive metabolizers) [79]. Wang et al. [147] also found that St. John's wort increased CYP2C19 activity, as revealed by the increased urinary 4 '-hydroxymephenytoin excretion in CYP2C19 wild-genotype subjects, but not in CYP2C19 poor metabolizers. Conversely, another clinical trial found that St. John's wort increased the clearance of fexofenadine (P-glycoprotein substrate) and midazolam (CYP3A4 substrate) in six ethnic groups (i.e. Caucasian, African American, Hispanic, Chinese, Indian and Malawy) and there was no significant difference in the extent of induction between the ethnic groups [151]. 


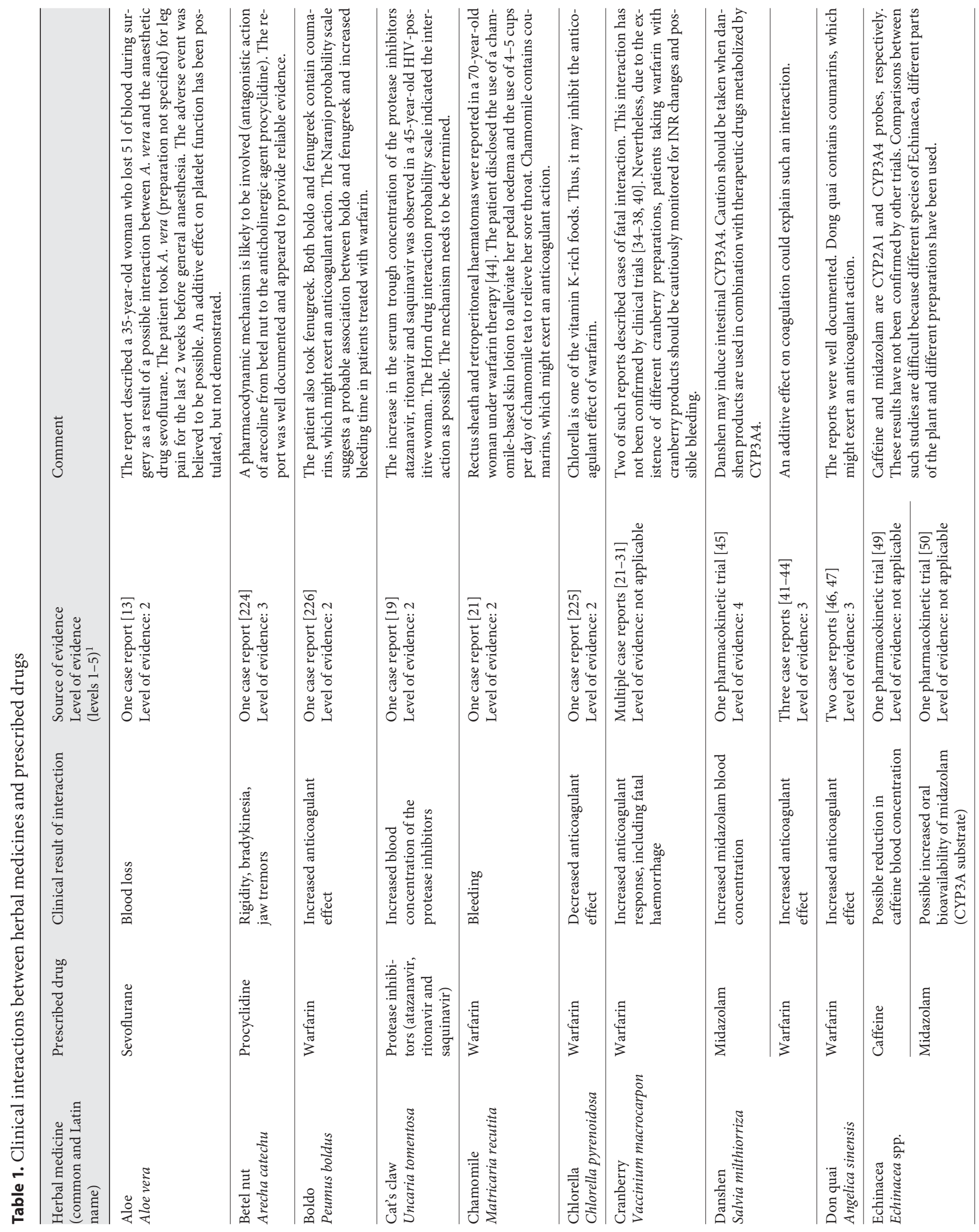




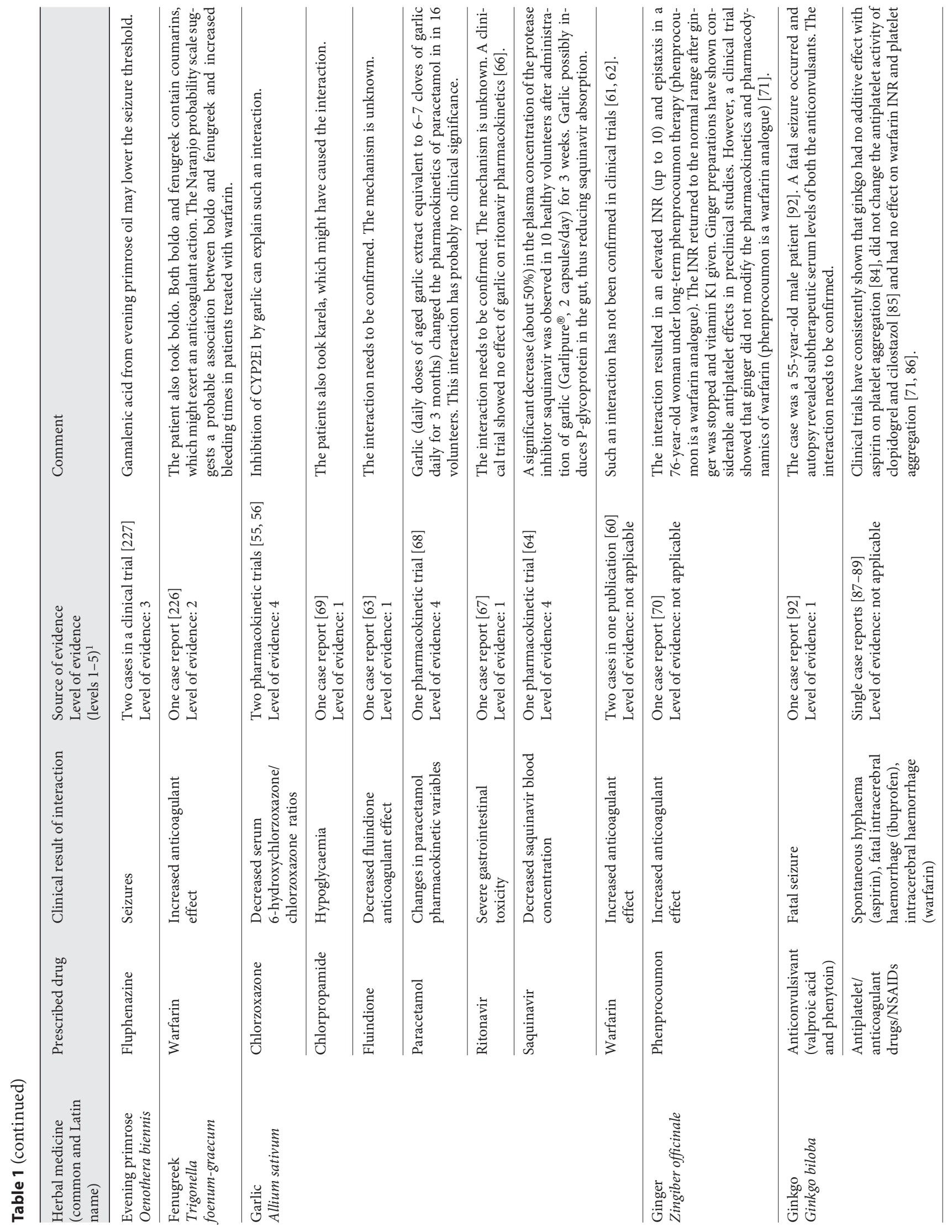




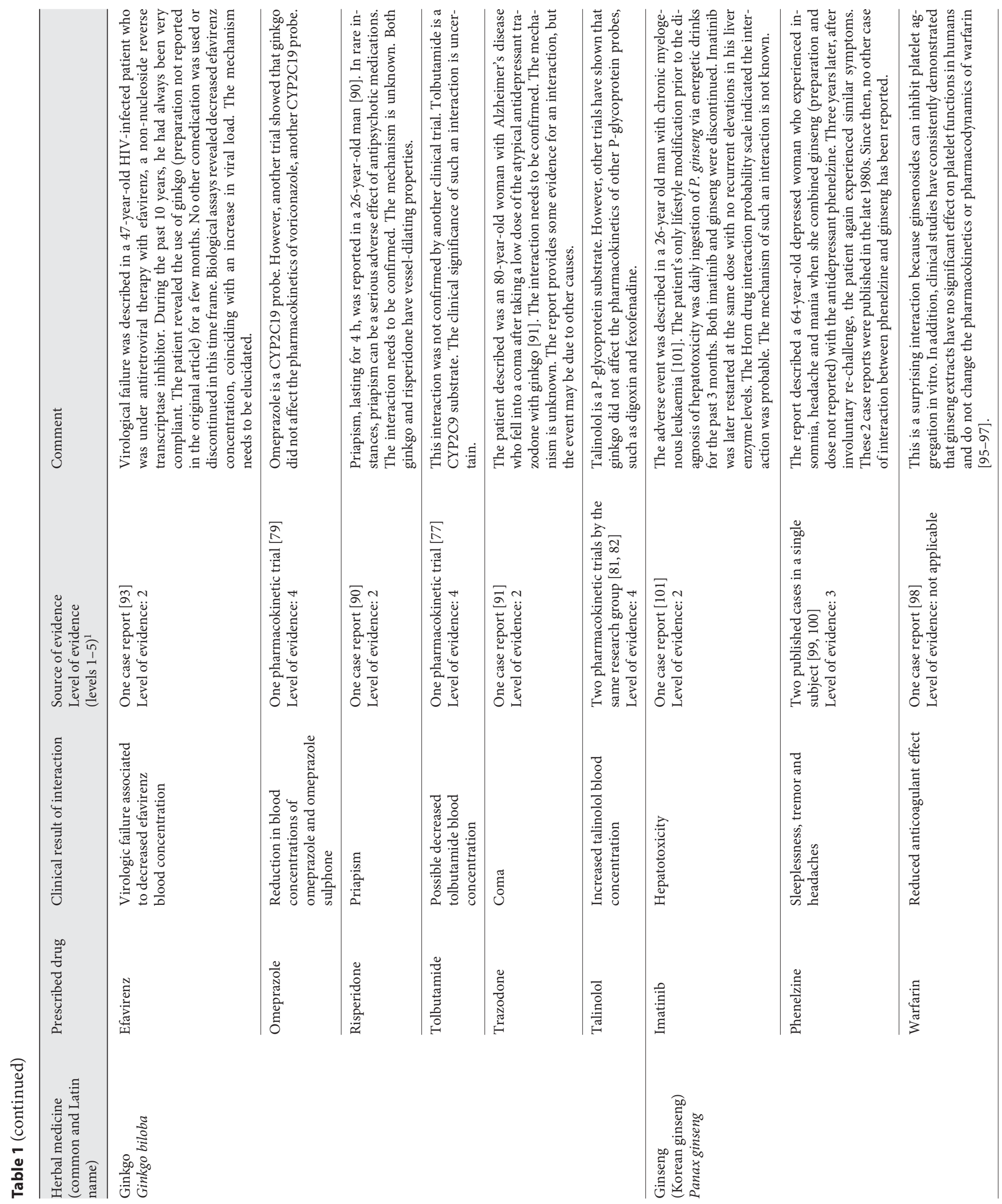




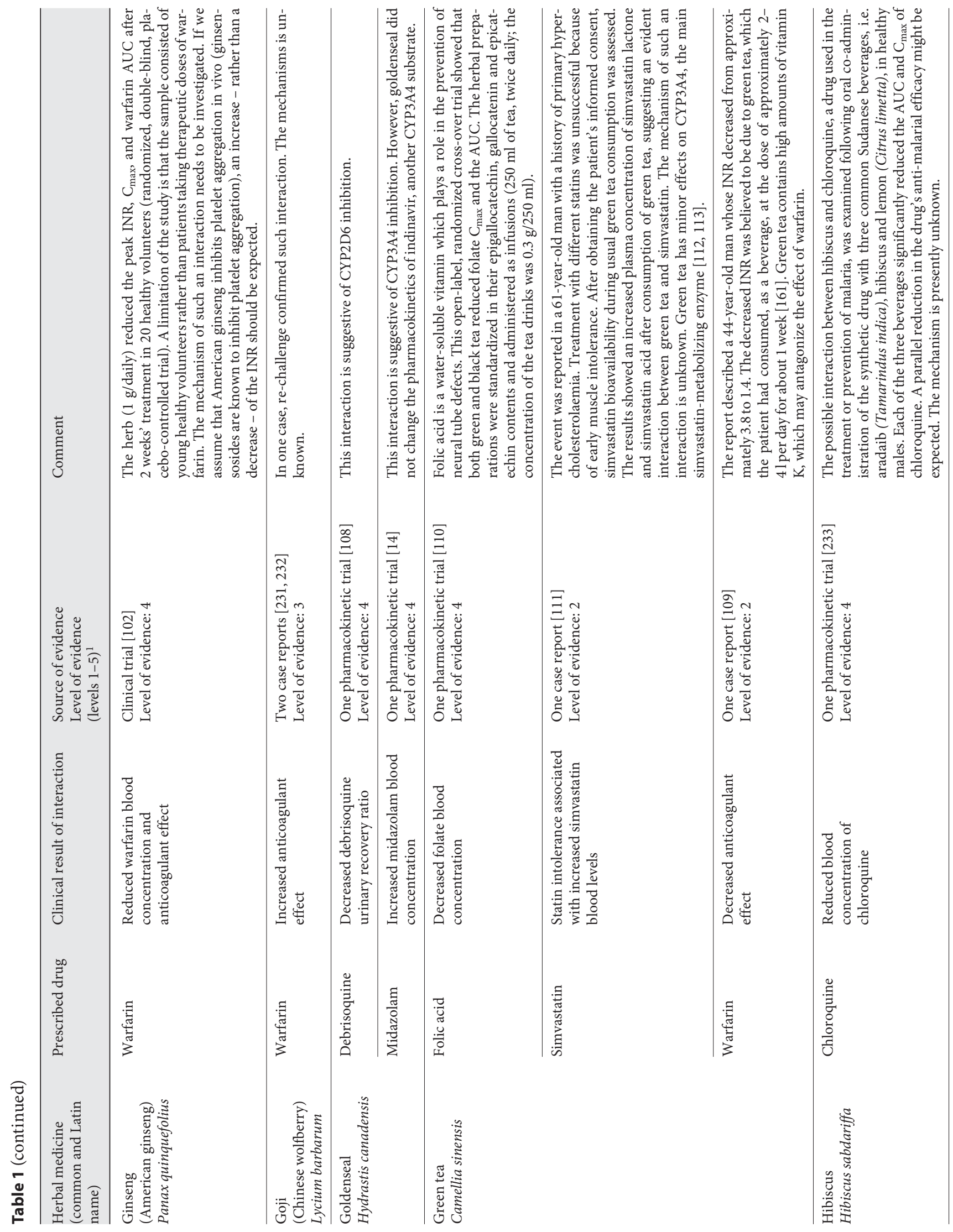




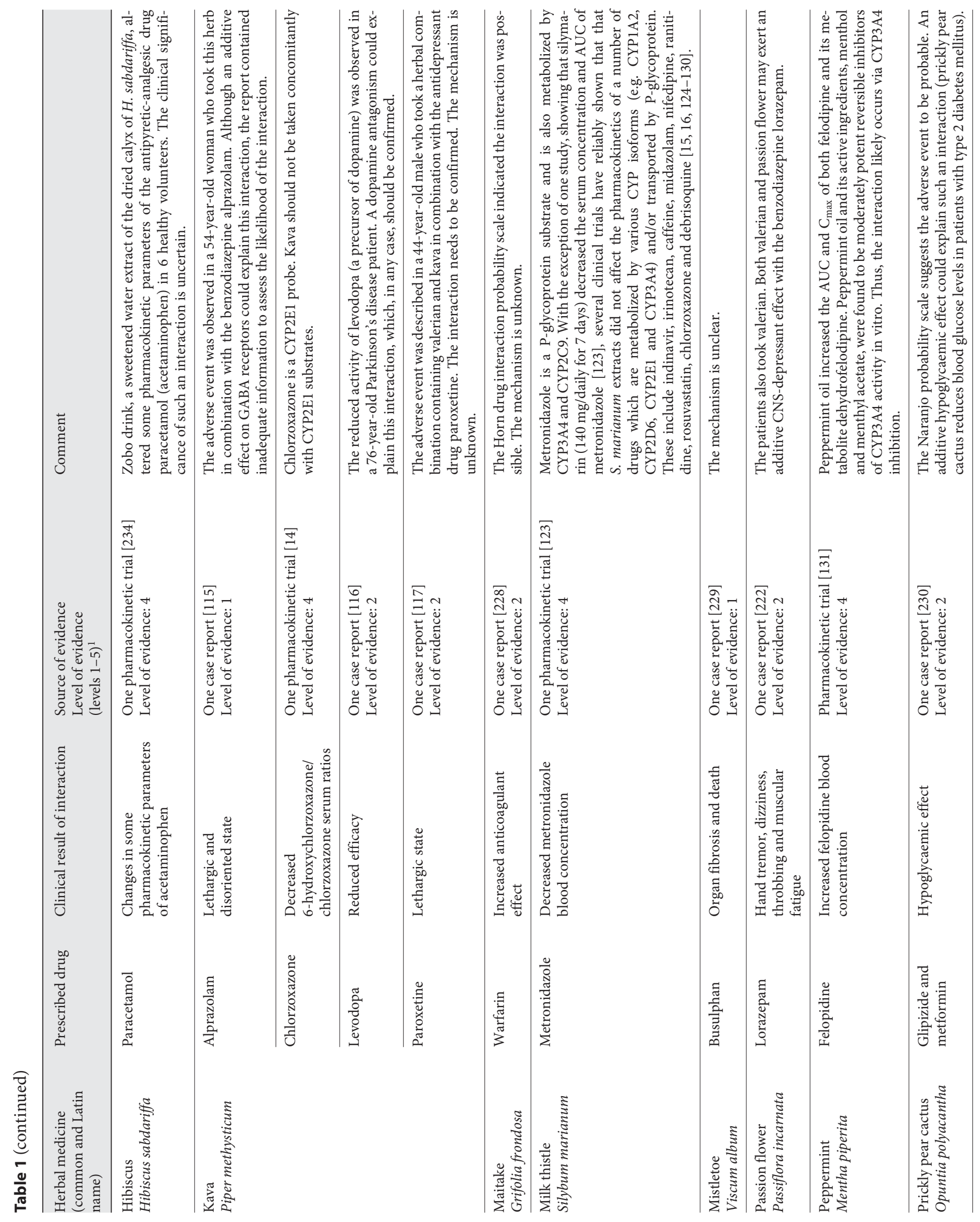




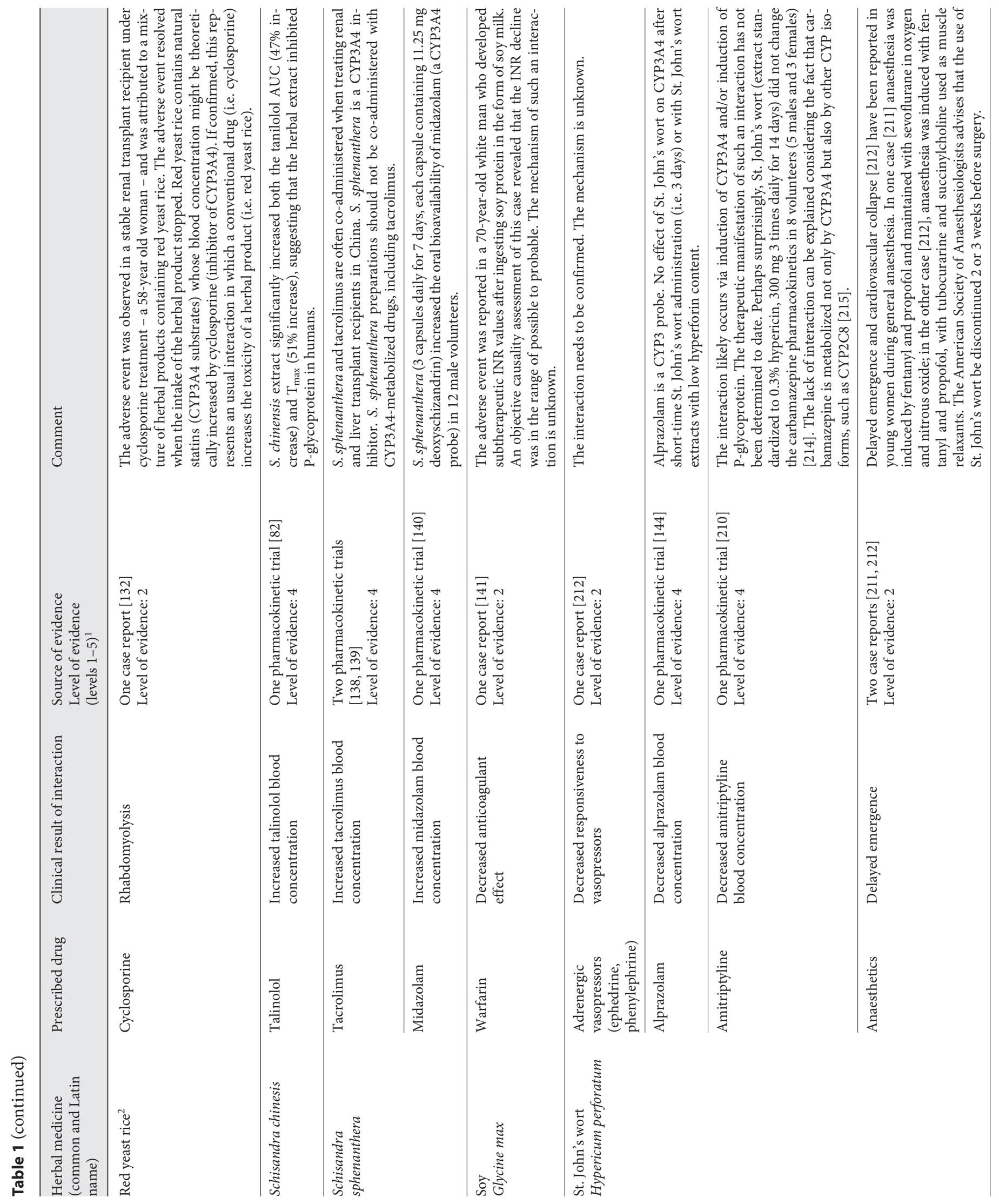




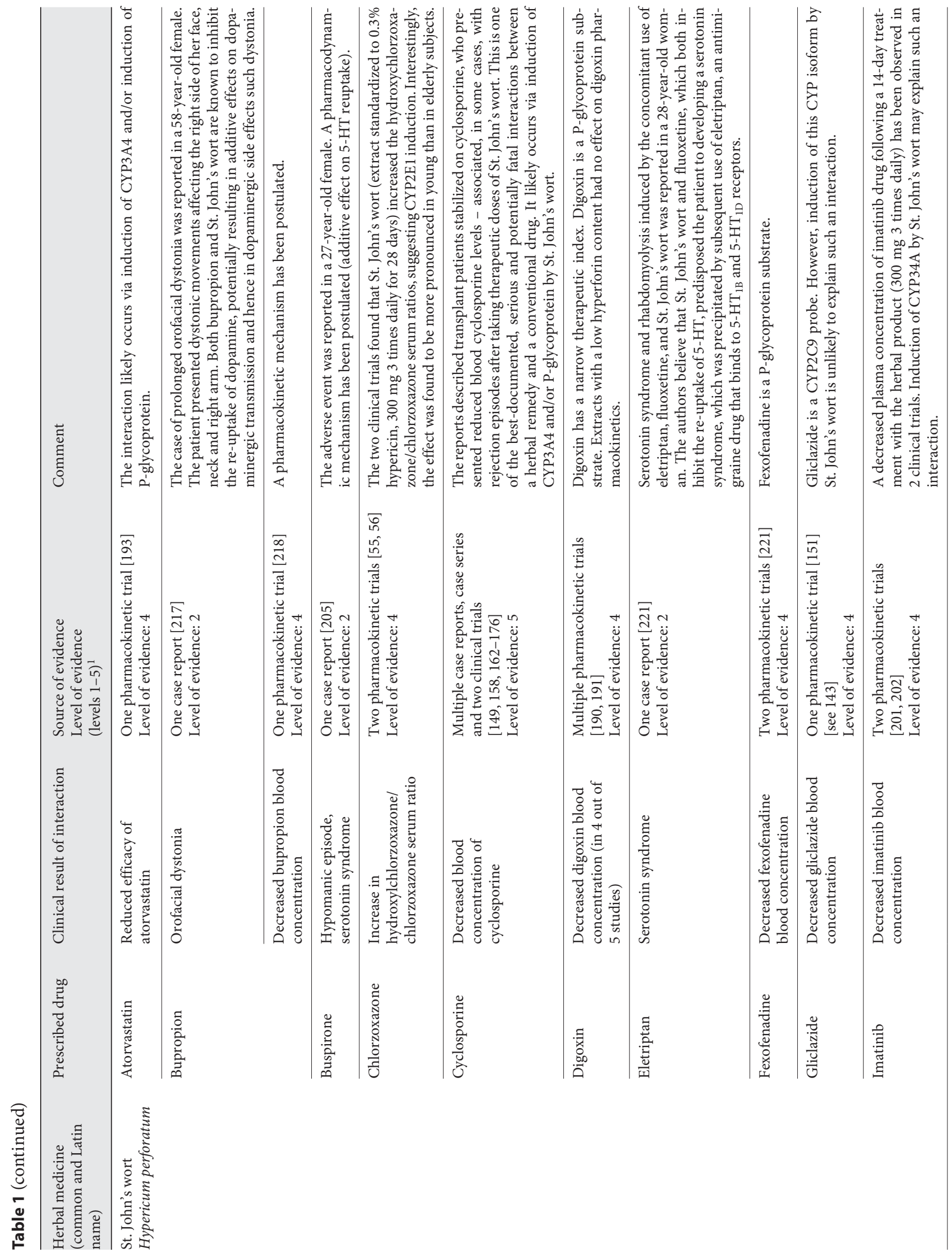




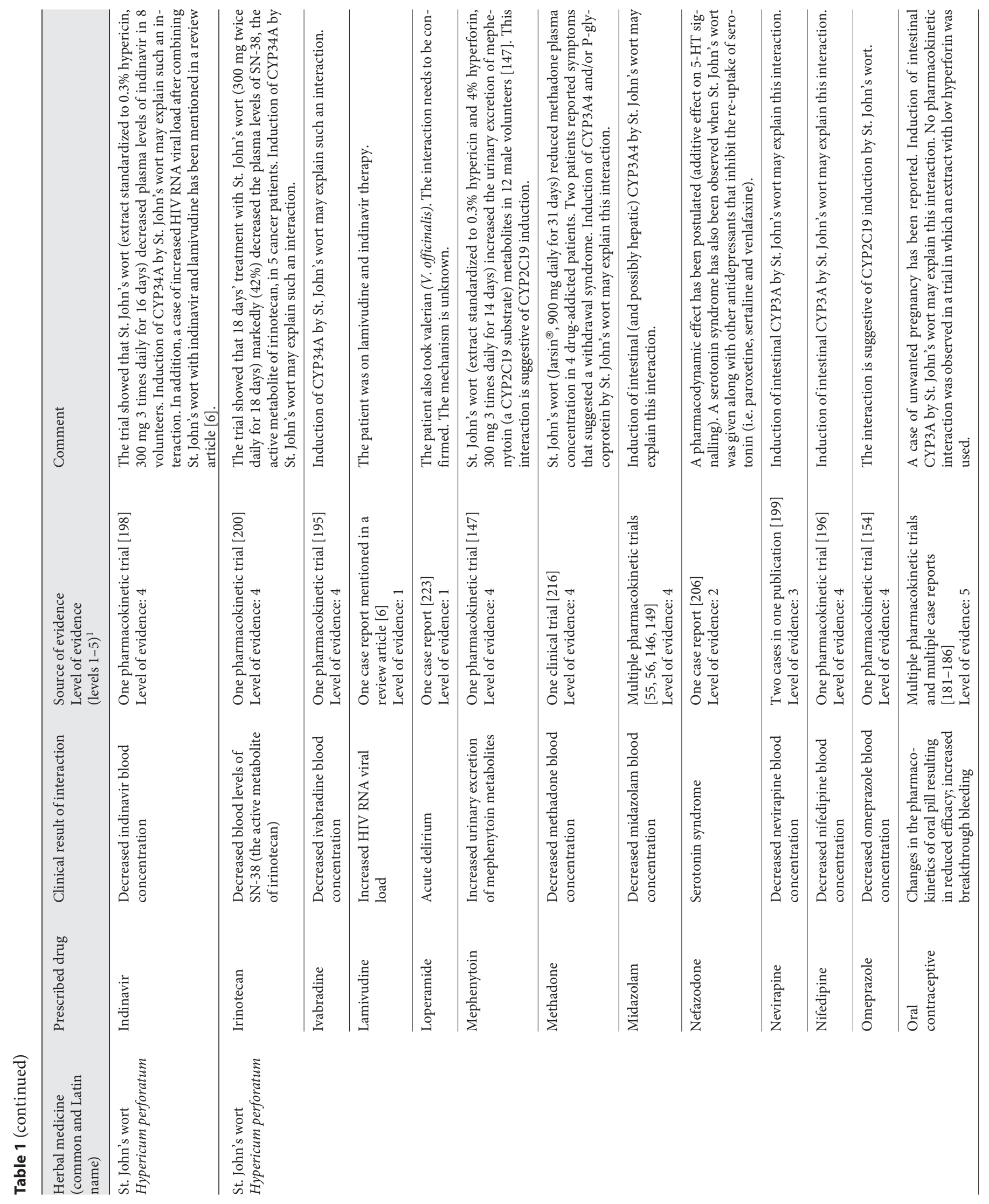




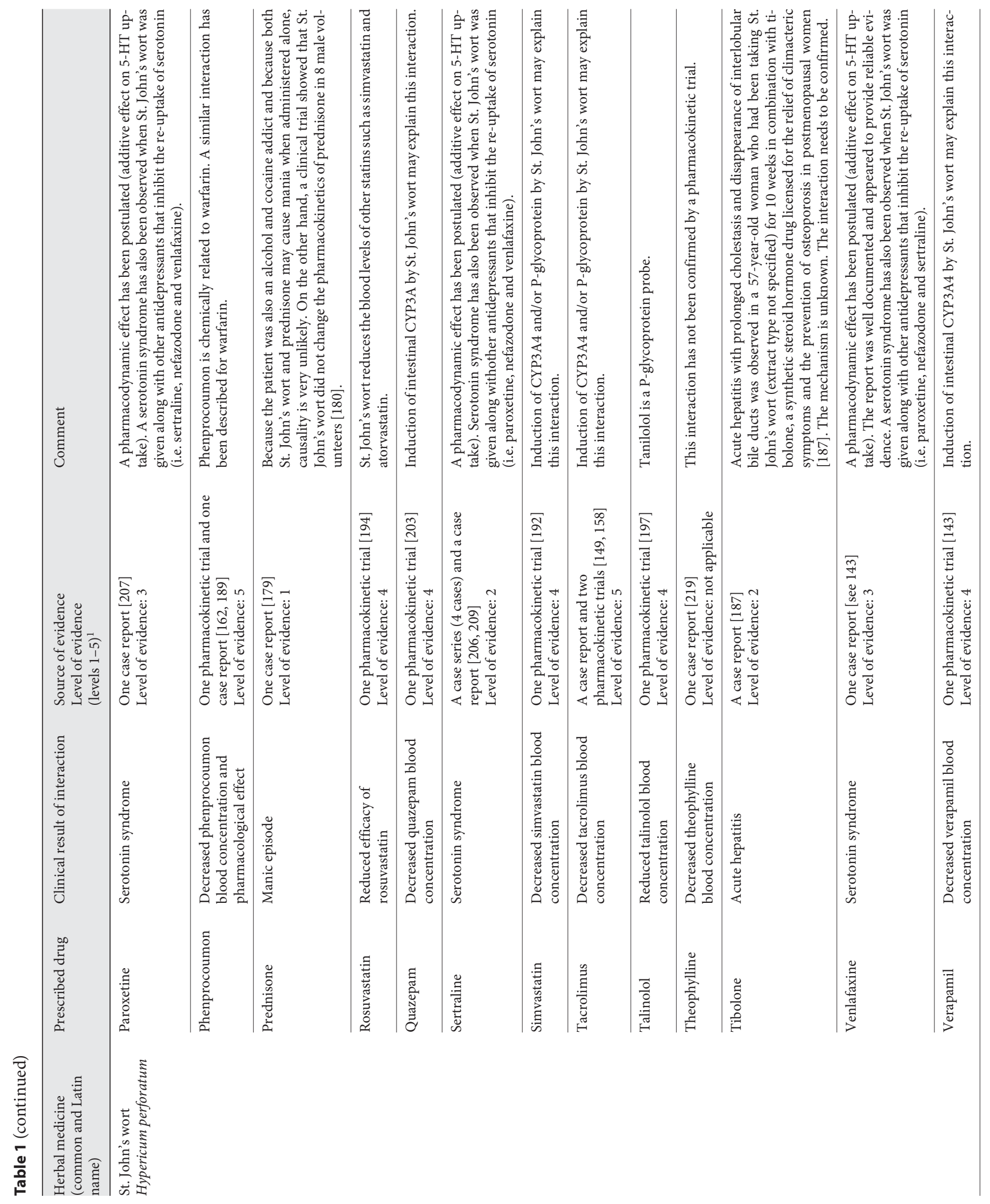




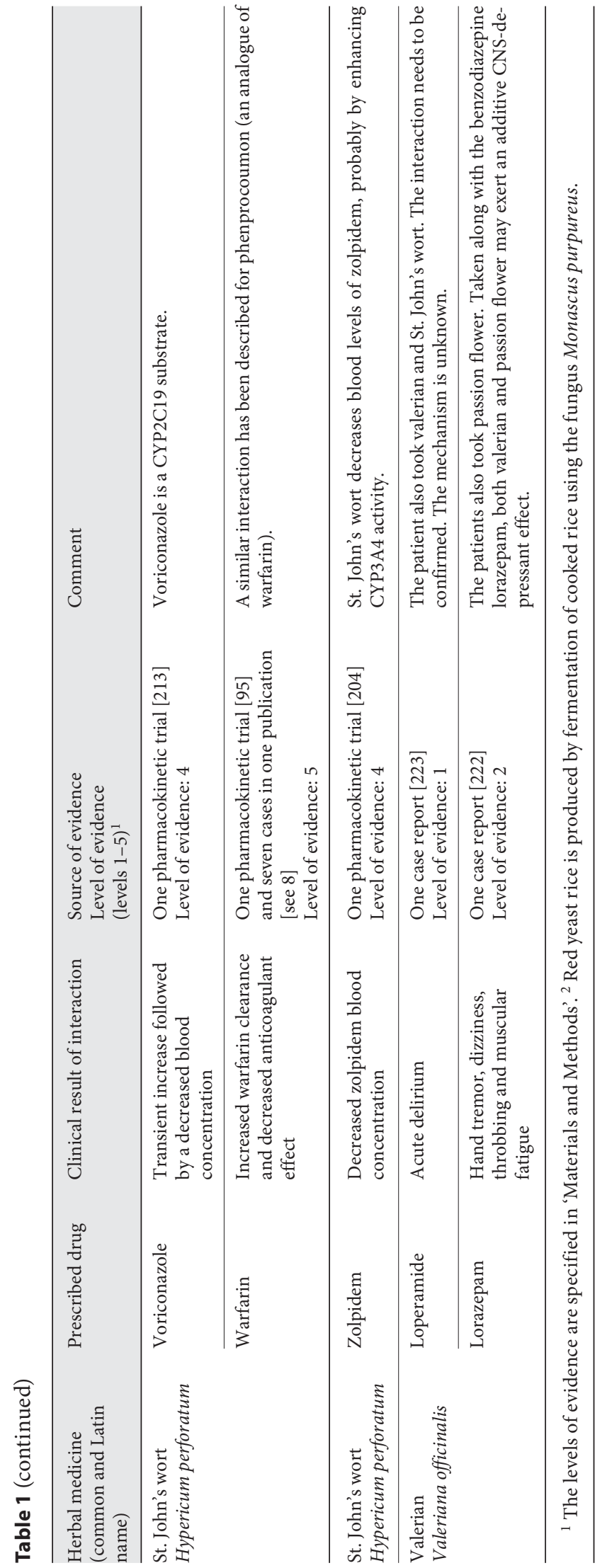

The concomitant use of prescription medications and herbal products by older adults is a common situation in western countries [243]. In addition, because older adults have multiple health problems, they are at particular risk for herb-to-drug interactions. Despite this, clinical studies aimed at investigating the potential of drug interaction in elderly patients are rare. Gurley et al. [55] found that elderly subjects, like their younger counterparts, are susceptible to herb-mediated changes in CYP activity and that some age-related changes in CYP responsivity to herbal products may exist. Specifically, it was found that ginseng slightly inhibited CYP2D6 in elderly subjects [55], in contrast to young subjects where no such inhibition was observed [56].

It is well established that the pharmacokinetics of many drugs may vary between men and women. Gender differences in herb-to-drug interactions have been reported both experimentally and in clinical trials. For example, a differential inductive profile of hepatic cytochrome P450s by the extracts of Sophora flavescens in male and female mice have recently been observed [244]. More importantly, Gurley et al. [56] reported a significant sex-related difference in the inductive ability of St. John's wort on CYP3A4 activity (i.e. St. John's wort induced CYP3A4 more marked in male than in female subjects).

\section{Patient Counselling}

The use of herbal medicines is widespread. A survey found that approximately $15 \%$ of patients receiving conventional pharmacotherapy also take herbal products, and among these, potential adverse herb-to-drug interactions were observed in $40 \%$ of patients [245]. It is therefore incumbent upon health care professionals to ask their patients about their use of herbal remedies. Patients erroneously believe that herbal products are natural and therefore safe. Probably for this reason, they are reluctant to disclose fully herbal use to their physicians. A recent study found that only $51.8 \%$ of women using complementary medicine, including herbal medicine, disclosed this use to their physician [246]. It is therefore imperative that patients, especially those under cardiovascular, immunosuppressant or antiretroviral therapy, be informed of the possible adverse effects caused by interactions between herbal products and conventional medicines. 


\section{Limitations}

This review article has several limitations: interactions were searched by consulting PubMed and Embase and by checking the reference list of relevant review articles dealing with herb-to-drug interactions. Only clinical reports were considered. Preclinical studies, including human in vitro experiments, were not considered. Even though the search strategy was meticulous, the author cannot affirm that all relevant clinical data have been retrieved.

A good deal of the evidence on herb-to-drug interactions discussed in this article is based on case reports, which are sometimes incomplete and do not allow one to infer a causal relationship. It is worth noting that even documented case reports can never establish a causal relationship between drug administration and an adverse event; in addition for many interactions listed in table 1, the evidence is far from conclusive, as sometimes only one case report has been used and in many cases, a poorly documented case report may have been published. In this article, the level of evidence has been categorized using a 5-point scoring system. The highest level of clinical evidence (i.e. level of evidence: 5) has been considered when an adverse event described in a case report has been confirmed by a clinical pharmacokinetic trial. On the other hand, many adverse events are supported by poorly documented case reports (level of evidence 1, see table 1 for further details). When pharmacokinetic trials have not confirmed the adverse event hypothesized on the basis of the published case report(s) (e.g. interactions between warfarin and cranberry or ginkgo) or when contradictory pharmacokinetic data were published, the level of evidence was defined as 'not applicable'. Although this scale has not been validated, it may be helpful as a guide for assessing whether an interaction is supported by adequate reliable clinical information.

In many instances, the extract type, standardization of extract, part of the plant used and the scientific (Latin) name of the plant have not been specified in clinical papers. This is an important omission because preparations obtained from the same plant may have different chemical compositions and hence different biological actions. Herbal preparations are not subject to the same regulations as prescription drugs and thus the content of the active ingredients may vary among manufacturers, potentially causing a large variation in efficacy and safety $[247,248]$.

The often underregulated quality of herbal medicines is another safety issue. Contamination or adulteration of herbal medicines, including adulteration with synthetic drugs, may be relatively frequent and can cause drug interactions $[2,3]$. In other words, the possibility that a contaminant/adulterant and not an herbal ingredient causes drug interactions cannot be ruled out.

As highlighted above, people who use herbal medicines tend to conceal this use to their physicians or pharmacists. This observation, together with the fact that in many countries there are no central mechanisms for mandatory reporting as there is for conventional medicine complicate the identification of most herb-to-drug interactions.

\section{Conclusion}

Clinical reports clearly indicate that herbal medicines can interact with conventional drugs. While the majority of such interactions may have a negligible clinical significance, some may pose a serious threat to public health. For example, combining St. John's wort with antiretroviral, immunosuppressive or anticancer agents that are metabolized by CYP enzymes and/or are substrates of P-glycoprotein may lead to drug failure. Serious health problems may occur when patients take herbal products before surgery. Cases of delayed emergence, cardiovascular collapse and loss of blood have been documented. A recent retrospective review of surgery patients presenting to the Anesthesia Preoperative Evaluation Clinic at the University of Kansas Hospital reported that approximately one-fourth of patients indicated the use of natural products prior the surgery [249]. It is therefore incumbent on clinicians to screen patients before surgery for use of these supplements.

In conclusion, herbal medicines may be used by patients concomitantly receiving conventional drugs, which can result in potentially serious adverse events. It is incumbent upon healthcare professionals to be well informed about the growing clinical evidence of herb-todrug interactions.

References al guidelines for methodologies on research and evaluation of traditional medicine. http://www.who.int/en/.

2 Ernst E, Pittler MH, Wider B: The Desktop Guide to Complementary and Alternative Medicine. An Evidence-Based Approach. Philadelphia, Mosby Elsevier, 2006.

3 Ernst E, Pittler MH, Wider B, Boddy K: Oxford Handbook of Complementary Medicine. Oxford, Oxford University Press, 2008. 
4 Capasso F, Gaginella TS, Grandolini G, Izzo AA: Phytotherapy. A Quick Reference to Herbal Medicine. Berlin, Springer-Verlag, 2003.

5 Blumenthal M: The Complete German Commission E Monographs. Austin, American Botanical Council, 1998.

-6 Zhou SF, Zhou ZW, Li CG, Chen X, Yu X, Xue CC, Herington A: Identification of drugs that interact with herbs in drug development. Drug Discov Today 2007;12:664-673.

7 Kennedy DA, Seely D: Clinically based evidence of drug-herb interactions: a systematic review. Expert Opin Drug Saf 2010;9: $79-124$.

$\checkmark 8$ Izzo AA, Ernst E: Interactions between herbal medicines and prescribed drugs: an updated systematic review. Drugs 2009;69:17771798.

$\checkmark 9$ Colalto C: Herbal interactions on absorption of drugs: mechanisms of action and clinical risk assessment. Pharmacol Res 2010;62: 207-227.

10 Zhou SF: Drugs behave as substrates, inhibitors and inducers of human cytochrome P450 3A4. Curr Drug Metab 2008;9:310-322.

- 11 Zhang W, Han Y, Lim SL, Lim LY: Dietary regulation of $\mathrm{P}$-gp function and expression. Expert Opin Drug Metab Toxicol 2009;5: 789-801.

12 Tomlinson B, Hu M, Lee VW: In vivo assessment of herb-drug interactions: possible utility of a pharmacogenetic approach? Mol Nutr Food Res 2008;52:799-809.

$\checkmark 13$ Lee A, Chui PT, Aun CS, Gin T, Lau AS: Possible interaction between sevoflurane and Aloe vera. Ann Pharmacother 2004;38:16511654.

-14 Gurley BJ, Gardner SF, Hubbard MA, Williams DK, Gentry WB, Khan IA, Shah A: In vivo effects of goldenseal, kava kava, black cohosh, and valerian on human cytochrome P450 1A2, 2D6, 2E1, and 3A4/5 phenotypes. Clin Pharmacol Ther 2005;77:415-426.

15 Gurley B, Hubbard MA, Williams DK, Thaden J, Tong Y, Gentry WB, Breen P, Carrier DJ, Cheboyina S: Assessing the clinical significance of botanical supplementation on human cytochrome P450 3A activity: comparison of a milk thistle and black cohosh product to rifampin and clarithromycin. J Clin Pharmacol 2006;46:201-213.

16 Gurley BJ, Barone GW, Williams DK, Carrier J, Breen P, Yates CR, Song PF, Hubbard MA, Tong Y, Cheboyina S: Effect of milk thistle (Silybum marianum) and black cohosh (Cimicifuga racemosa) supplementation on digoxin pharmacokinetics in humans. Drug Metab Dispos 2006;34:69-74.

17 Gurley BJ, Swain A, Hubbard MA, Williams DK, Barone G, Hartsfield F, Tong Y, Carrier DJ, Cheboyina S, Battu SK: Clinical assessment of CYP2D6-mediated herb-drug interactions in humans: effects of milk thistle, black cohosh, goldenseal, kava kava, St John's wort, and Echinacea. Mol Nutr Food Res 2008;52:755-763.
18 Wanwimolruk S, Wong K, Wanwimolruk P: Variable inhibitory effect of different brands of commercial herbal supplements on human cytochrome P-450 CYP3A4. Drug Metabol Drug Interact 2009;24:17-35.

19 López Galera RM, Ribera Pascuet E, Esteban Mur JI, Montoro Ronsano JB, Juárez Giménez JC: Interaction between cat's claw and protease inhibitors atazanavir, ritonavir and saquinavir. Eur J Clin Pharmacol 2008;64: 1235-1236.

20 No Author listed: Herb-drug interactions: reported vs potential effects; in Rotblatt $\mathrm{M}$, Ziment I (eds): Evidence-Based Herbal Medicine. Philadelphia, Hanley \& Belfus, 2002, pp 45-55.

21 Segal R, Pilote L: Warfarin interaction with Matricaria chamomilla. CMAJ 2006;174: 1281-1282.

22 MHRA/CSM: Interaction between warfarin and cranberry juice. New advice. Curr Probl Pharmacovigil 2003;30:10.

23 Aston JL, Lodolce AE, Shapiro NL: Interaction between warfarin and cranberry juice. Pharmacotherapy 2006;26:1314-1319.

24 Pham DQ, Pham AQ: Interaction potential between cranberry juice and warfarin. Am J Health Syst Pharm 2007;64:490-494.

25 Mergenhagen KA, Sherman O: Elevated International Normalized Ratio after concurrent ingestion of cranberry sauce and warfarin. Am J Health Syst Pharm 2008;65:21132116.

26 Griffiths AP, Beddall A, Pegler S: Fatal haemopericardium and gastrointestinal haemorrhage due to possible interaction of cranberry juice with warfarin. J R Soc Promot Health 2008;128:324-326.

27 Suvarna R, Pirmohamed M, Henderson L: Possible interaction between warfarin and cranberry juice. BMJ 2003;327:1454.

28 Grant P: Warfarin and cranberry juice: an interaction? J Heart Valve Dis 2004;13:25-56.

29 Paeng CH, Sprague M, Jackevicius CA: Interaction between warfarin and cranberry juice. Clin Ther 2007;29:1730-1735.

30 Rindone JP, Murphy TW: Warfarin-cranberry juice interaction resulting in profound hypoprothrombinemia and bleeding. Am J Ther 2006;13:283-284.

- 31 Paeng CH, Sprague M, Jackevicius CA: Interaction between warfarin and cranberry juice. Clin Ther 2007;29:1730-1735.

32 Zikria J, Goldman R, Ansell J: Cranberry juice and warfarin: when bad publicity trumps science. Am J Med 2010;123:384-392.

33 Mohammed Abdul MI, Jiang X, Williams KM, Day RO, Roufogalis BD, Liauw WS, Xu $\mathrm{H}$, McLachlan AJ: Pharmacodynamic interaction of warfarin with cranberry but not with garlic in healthy subjects. Br J Pharmacol 2008; 154:1691-1700.

34 Li Z, Seeram NP, Carpenter CL, Thames G, Minutti C, Bowerman S: Cranberry does not affect prothrombin time in male subjects on warfarin. J Am Diet Assoc 2006; 106:20572061.
5 Ansell J, McDonough M, Zhao Y, Harmatz JS, Greenblatt DJ: The absence of an interaction between warfarin and cranberry juice: a randomized, double-blind trial. J Clin Pharmacol 2009;49:824-830.

36 Lilja JJ, Backman JT, Neuvonen PJ: Effects of daily ingestion of cranberry juice on the pharmacokinetics of warfarin, tizanidine, and midazolam-probes of CYP2C9, CYP1A2, and CYP3A4. Clin Pharmacol Ther 2007;81:833-839.

37 Greenblatt DJ, von Moltke LL, Perloff ES, Luo Y, Harmatz JS, Zinny MA: Interaction of flurbiprofen with cranberry juice, grape juice, tea, and fluconazole: in vitro and clinical studies. Clin Pharmacol Ther 2006;79: 125-133.

38 Ushijima K, Tsuruoka S, Tsuda H, Hasegawa G, Obi Y, Kaneda T, Takahashi M, Maekawa T, Sasaki T, Koshimizu TA, Fujimura A: Cranberry juice suppressed the diclofenac metabolism by human liver microsomes, but not in healthy human subjects. Br J Clin Pharmacol 2009;68:194-200.

- 39 Pham DQ, Pham AQ: Interaction potential between cranberry juice and warfarin. Am J Health Syst Pharm 2007;64:490-494.

40 Grenier J, Fradette C, Morelli G, Merritt GJ, Vranderick M, Ducharme MP: Pomelo juice, but not cranberry juice, affects the pharmacokinetics of cyclosporine in humans. Clin Pharmacol Ther 2006;79:255-262.

41 Chan TY: Interaction between warfarin and danshen (Salvia miltiorrhiza). Ann Pharmacother 2001;35:501-504

42 Izzat MB, Yim AP, El-Zufari MH: A taste of Chinese medicine. Ann Thorac Surg 1998; 66:941-942.

43 Tam LS, Chan TY, Leung WK, Critchley JA Warfarin interactions with Chinese traditional medicines: danshen and methyl salicylate medicated oil. Aust NZ J Med 1995;25:258.

44 Yu CM, Chan JC, Sanderson JE: Chinese herbs and warfarin potentiation by danshen. J Intern Med 1997;25:337-339.

45 Qiu F, Wang G, Zhang R, Sun J, Jiang J, Ma Y: Effect of danshen extract on the activity of CYP3A4 in healthy volunteers. Br J Clin Pharmacol 2010;69:656-662.

46 Ellis GR, Stephens MR: Untitled (photograph and brief case report). BMJ 1999;19: 650

47 Page RL, Lawrence JD: Potentiation of warfarin by dong quai. Pharmacotherapy 1999; 319:870-876

48 Gurley BJ, Swain A, Williams DK, Barone G, Battu SK: Gauging the clinical significance of P-glycoprotein-mediated herb-drug interactions: comparative effects of St John's wort, Echinacea, clarithromycin, and rifampin on digoxin pharmacokinetics. $\mathrm{Mol}$ Nutr Food Res 2008;52:772-779. 
49 Gurley BJ, Gardner SF, Hubbard MA, Williams DK, Gentry WB, Carrier J, Khan IA, Edwards DJ, Shah A: In vivo assessment of botanical supplementation on human cytochrome P450 phenotypes: Citrus aurantium, Echinacea purpurea, milk thistle, and saw palmetto. Clin Pharmacol 2004;76:428 440

-50 Gorski JC, Huang SM, Pinto A, Hamman MA, Hilligoss JK, Zaheer NA, Desai M, Miller M, Hall SD: The effect of echinacea (Echinacea purpurea root) on cytochrome P450 activity in vivo. Clin Pharmacol Ther 2004; 75:89-100.

51 Moltó J, Valle M, Miranda C, Cedeño S, Negredo E, Barbanoj MJ, Clotet B: Herb-drug interaction between Echinacea purpurea and darunavir-ritonavir in HIV-infected patients. Antimicrob Agents Chemother 2011;55:326-330.

-52 Donovan JL, DeVane CL, Chavin KD, Taylor RM, Markowitz JS: Siberian ginseng (Eleutheroccus senticosus) effects on CYP2D6 and CYP3A4 activity in normal volunteers. Drug Metab Dispos 2003;31:519-522.

53 McRae S: Elevated serum digoxin levels in a patient taking digoxin and Siberian ginseng. CMAJ 1996;155:293-295.

54 Markowitz JS, Devane CL, Chavin KD, Taylor RM, Ruan Y, Donovan JL: Effects of garlic (Allium sativum L.) supplementation on cytochrome P450 2D6 and 3A4 activity in healthy volunteers. Clin Pharmacol Ther 2003;74:170-177.

-55 Gurley BJ, Gardner SF, Hubbard MA, Williams DK, Gentry WB, Cui Y, Ang CY: Clinical assessment of effects of botanical supplementation on cytochrome $\mathrm{P} 450$ phenotypes in the elderly: St John's wort, garlic oil, Panax ginseng and Ginkgo biloba. Drugs Aging 2005;22:525-539.

-56 Gurley BJ, Gardner SF, Hubbard MA, Williams DK, Gentry WB, Cui Y, Ang CY: Cytochrome $\mathrm{P} 450$ phenotypic ratios for predicting herb-drug interactions in humans. Clin Pharmacol Ther 2002;72:276-287.

- 57 Jabbari A, Argani H, Ghorbanihaghjo A, Mahdavi R: Comparison between swallowing and chewing of garlic on levels of serum lipids, cyclosporine, creatinine and lipid peroxidation in renal transplant recipients. Lipids Health Dis 2005;4:11.

58 Cox MC, Low J, Lee J, Walshe J, Denduluri N, Berman A, Permenter MG, Petros WP Price DK, Figg WD, Sparreboom A, Swain SM: Influence of garlic (Allium sativum) on the pharmacokinetics of docetaxel. Clin Cancer Res 2006; 12:4636-4640.

59 Hajda J, Rentsch KM, Gubler C, Steinert H, Stieger B, Fattinger K: Garlic extract induces intestinal P-glycoprotein, but exhibits no effect on intestinal and hepatic CYP3A4 in humans. Eur J Pharm Sci 2010;41:729-735.

60 Sunter WH: Warfarin and garlic. Pharm J 1991;246:772.

61 Macan H, Uykimpang R, Alconcel M, Takasu J, Razon R, Amagase H, Niihara Y: Aged garlic extract may be safe for patients on warfarin therapy. J Nutr 2006;136:793S-795S.

62 Abdul MMI, Jiang X, Williams KM, Day RO, Roufogalis BD, Liauw WS, Xu H, McLachlan AJ: Pharmacodynamic interaction of warfarin with cranberry but not with garlic in healthy subjects. Br J Pharmacol 2008;154:1691-1700.

63 Pathak A, Léger P, Bagheri H, Senard JM, Boccalon H, Montastruc JL: Garlic interaction with fluindione: a case report. Therapie 2003;58:380-381.

64 Piscitelli SC, Burstein AH, Welden N, Gallicano KD, Falloon J: The effect of garlic supplements on the pharmacokinetics of saquinavir. Clin Infect Dis 2002;34:234-238.

65 Berginc K, Trdan T, Trontelj J, Kristl A: HIV protease inhibitors: garlic supplements and first-pass intestinal metabolism impact on the therapeutic efficacy. Biopharm Drug Dispos 2010;31:495-505.

66 Gallicano K, Foster B, Choudhri S: Effect of short-term administration of garlic supplements on single-dose ritonavir pharmacokinetics in healthy volunteers. Br J Clin Pharmacol 2003;55:199-202.

67 Laroche M, Choudhuri S, Gallicano K, Foster B: Severe gastrointestinal toxicity with concomitant ingestion of ritonavir and garlic. Can J Infect Dis 1998;9:471P.

68 Gwilt PR, Lear CL, Tempero MA, Birt DD, Grandjean AC, Ruddon RW, Nagel DL: The effect of garlic extract on human metabolism of acetaminophen. Cancer Epidemiol Biomarkers Prev 1994;3:155-160.

69 Aslam M, Stockley IH: Interaction between curry ingredient (karela) and drug (chlorpropamide). Lancet 1979;i:607.

70 Krüth P, Brosi E, Fux R, Mörike K, Gleiter $\mathrm{CH}$ : Ginger-associated overanticoagulation by phenprocoumon. Ann Pharmacother 2004;38:257-260.

71 Jiang X, Williams KM, Liauw WS, Ammit AJ, Roufogalis BD, Duke CC, Day RO, McLachlan AJ: Effect of ginkgo and ginger on the pharmacokinetics and pharmacodynamics of warfarin in healthy subjects. $\mathrm{Br} \mathrm{J}$ Clin Pharmacol 2005;59:425-432.

72 Markowitz JS, Donovan JL, Lindsay DeVane C, Sipkes L, Chavin KD: Multiple-dose administration of Ginkgo biloba did not affect cytochrome P-450 2D6 or 3A4 activity in normal volunteers. J Clin Psychopharmacol 2003;23:576-581.

73 Mohutsky MA, Anderson GD, Miller JW, Elmer GW: Ginkgo biloba: evaluation of CYP2C9 drug interactions in vitro and in vivo. Am J Ther 2006;13:24-31.

74 Mauro VF, Mauro LS, Kleshinski JF, Khuder SA, Wang Y, Erhardt PW: Impact of Ginkgo biloba on the pharmacokinetics of digoxin. Am J Ther 2003; 10:247-251.

75 Robertson SM, Davey RT, Voell J, Formentini E, Alfaro RM, Penzak SR: Effect of Ginkgo biloba extract on lopinavir, midazolam and fexofenadine pharmacokinetics in healthy subjects. Curr Med Res Opin 2008; 24:591-599.
76 Greenblatt DJ, von Moltke LL, Luo Y, Perloff ES, Horan KA, Bruce A, Reynolds RC, Harmatz JS, Avula B, Khan IA, Goldman P: Ginkgo biloba does not alter clearance of flurbiprofen, a cytochrome P450-2C9 substrate. J Clin Pharmacol 2006;46:214-221.

77 Uchida S, Yamada H, Li XD, Maruyama S, Ohmori Y, Oki T, Watanabe H, Umegaki K, Ohashi K, Yamada S: Effects of Ginkgo biloba extract on pharmacokinetics and pharmacodynamics of tolbutamide and midazolam in healthy volunteers. J Clin Pharmacol 2006; 46:1290-1298

-78 Yoshioka M, Ohnishi N, Koishi T, Obata Y, Nakagawa M, Matsumoto T, Tagagi K, Takara K, Ohkuni T, Yokoyama T, Kuroda K: Studies on interactions between functional foods or dietary supplements and medicines. IV. Effects of Ginkgo biloba leaf extract on the pharmacokinetics and pharmacodynamics of nifedipine in healthy volunteers. Biol Pharm Bull 2004;27:2006-2009.

79 Yin OQ, Tomlinson B, Waye MM, Chow AH, Chow MS: Pharmacogenetics and herb-drug interactions: experience with Ginkgo biloba and omeprazole. Pharmacogenetics 2004; 14 : 841-850.

80 Zuo XC, Zhang BK, Jia SJ, Liu SK, Zhou LY, Li J, Zhang J, Dai LL, Chen BM, Yang GP, Yuan H: Effects of Ginkgo biloba extracts on diazepam metabolism: a pharmacokinetic study in healthy Chinese male subjects. Eur J Clin Pharmacol 2010;66:503-509.

81 Fan L, Tao GY, Wang G, Chen Y, Zhang W, He YJ, Li Q, Lei HP, Jiang F, Hu DL, Huang YF, Zhou HH: Effects of Ginkgo biloba extract ingestion on the pharmacokinetics of talinolol in healthy Chinese volunteers. Ann Pharmacother 2009;43:944-949.

82 Fan L, Mao XQ, Tao GY, Wang G, Jiang F, Chen Y, Li Q, Zhang W, Lei HP, Hu DL, Huang YF, Wang D, Zhou HH: Effect of Schisandra chinensis extract and Ginkgo biloba extract on the pharmacokinetics of talinolol in healthy volunteers. Xenobiotica 2009;39:249-254.

83 Bone KM: Potential interaction of Ginkgo biloba leaf with antiplatelet or anticoagulant drugs: what is the evidence? Mol Nutr Food Res 2008;52:764-771.

84 Aruna D, Naidu MU: Pharmacodynamic interaction studies of Ginkgo biloba with cilostazol and clopidogrel in healthy human subjects. Br J Clin Pharmacol 2007;63:333338

85 Jiang X, Williams KM, Liauw WS, Ammit AJ, Roufogalis BD, Duke CC, Day RO, McLachlan AJ: Effect of ginkgo and ginger on the pharmacokinetics and pharmacodynamics of warfarin in healthy subjects. Br J Clin Pharmacol 2005;59:425-432.

86 Engelsen J, Nielsen JD, Winther K: Effect of coenzyme Q10 and Ginkgo biloba on warfarin dosage in stable, long-term warfarintreated outpatients. A randomised, double blind, placebo-crossover trial. Thromb Haemost 2002;87:1075-1076. 
87 Rosenblatt M, Mindel J: Spontaneous hyphema associated with ingestion of Ginkgo biloba extract. N Engl J Med 1997;336:1108.

88 Matthews MK Jr: Association of Ginkgo biloba with intracerebral hemorrhage. Neurology 1998;50:1933-1934.

89 Meisel C, Johne A, Roots I: Fatal intracerebral mass bleeding associated with Ginkgo biloba and ibuprofen. Atherosclerosis 2003; 167:367.

90 Lin YY, Chu SJ, Tsai SH: Association between priapism and concurrent use of risperidone and Ginkgo biloba. Mayo Clin Proc 2007;82:1289-1290.

91 Galluzzi S, Zanetti O, Binetti G, Trabucchi $\mathrm{M}$, Frisoni GB: Coma in a patient with Alzheimer's disease taking low dose trazodone and Gingko biloba. J Neurol Neurosurg Psychiatry 2000;68:679-680.

92 Kupiec T, Raj V: Fatal seizures due to potential herb-drug interactions with Ginkgo biloba. J Anal Toxicol 2005;29:755-758.

-93 Wiegman DJ, Brinkman K, Franssen EJ: Interaction of Ginkgo biloba with efavirenz. AIDS 2009;23:1184-1185.

-94 Beckert BW, Concannon MJ, Henry SL, Smith DS, Puckett CL: The effect of herbal medicines on platelet function: an in vivo experiment and review of the literature. Plast Reconstr Surg 2007;120:2044-2050.

$\$ 95$ Jiang X, Williams KM, Liauw WS, Ammit AJ, Roufogalis BD, Duke CC, Day RO, McLachlan AJ: Effect of St John's wort and ginseng on the pharmacokinetics and pharmacodynamics of warfarin in healthy subjects. Br J Clin Pharmacol 2004;57: 592-599.

-96 Lee SH, Ahn YM, Ahn SY, Doo HK, Lee BC: Interaction between warfarin and Panax ginseng in ischemic stroke patients. J Altern Complement Med 2008;14:715-721.

\$97 Lee YH, Lee BK, Choi YJ, Yoon IK, Chang $\mathrm{BC}, \mathrm{Gwak}$ HS: Interaction between warfarin and Korean red ginseng in patients with cardiac valve replacement. Int J Cardiol 2010;145:275-276.

$\$ 98$ Janetzky K, Morreale AP: Probable interaction between warfarin and ginseng. Am J Health Syst Pharm 1997;54:692-693.

-99 Shader RI, Greenblatt DJ: Bees, ginseng and MAOIs revisited. J Clin Psychopharmacol 1988;8:235.

100 Jones BD, Runikis AM: Interaction of ginseng with phenelzine. J Clin Psychopharmacol 1987;7:201-202.

101 Bilgi N, Bell K, Ananthakrishnan AN, Atallah E: Imatinib and Panax ginseng: a potential interaction resulting in liver toxicity. Ann Pharmacother 2010;44:926-928.

102 Yuan CS, Wei G, Dey L, Karrison T, Nahlik L, Maleckar S, Kasza K, Ang-Lee M, Moss $\mathrm{J}$ : Brief communication: American ginseng reduces warfarin's effect in healthy patients: a randomized, controlled trial. Ann Intern Med 2004;141:23-27.

- 103 Andrade AS, Hendrix C, Parsons TL, Ca- 115 ballero B, Yuan CS, Flexner CW, Dobs AS,
Brown TT: Pharmacokinetic and metabolic effects of American ginseng (Panax quinquefolius) in healthy volunteers receiving the HIV protease inhibitor indinavir. BMC Complement Altern Med 2008;8:50.

104 Lee LS, Wise SD, Chan C, Parsons TL, Flexner C, Lietman PS: Possible differential induction of phase 2 enzyme and antioxidant pathways by American ginseng, Panax quinquefolius. J Clin Pharmacol 2008;48: 599-609.

105 Gurley BJ, Swain A, Barone GW, Williams DK, Breen P, Yates CR, Stuart LB, Hubbard MA, Tong Y, Cheboyina S: Effect of goldenseal (Hydrastis canadensis) and kava kava (Piper methysticum) supplementation on digoxin pharmacokinetics in humans. Drug Metab Dispos 2007;35:240-245.

106 Sandhu RS, Prescilla RP, Simonelli TM, Edwards DJ: Influence of goldenseal root on the pharmacokinetics of indinavir. J Clin Pharmacol 2003;43:1283-1288.

107 Gurley BJ, Swain A, Hubbard MA, Hartsfield F, Thaden J, Williams DK, Gentry WB, Tong Y: Supplementation with goldenseal (Hydrastis canadensis), but not kava kava (Piper methysticum), inhibits human CYP3A activity in vivo. Clin Pharmacol Ther 2008;83:61-69.

108 Gurley BJ, Gardner SF, Hubbard MA, Williams DK, Gentry WB, Khan IA, Shah A: In vivo effects of goldenseal, kava kava, black cohosh, and valerian on human cytochrome P450 1A2, 2D6, 2E1, and 3A4/5 phenotypes. Clin Pharmacol Ther 2005;77:415-426.

109 Taylor JR, Wilt VM: Probable antagonism of warfarin by green tea. Ann Pharmacother 1999;33:426-428.

110 Alemdaroglu NC, Dietz U, Wolffram S, Spahn-Langguth H, Langguth P: Influence of green and black tea on folic acid pharmacokinetics in healthy volunteers: potential risk of diminished folic acid bioavailability. Biopharm Drug Dispos 2008;29:335-348.

111 Werba JP, Giroli M, Cavalca V, Nava MC, Tremoli E, Dal Bo L: The effect of green tea on simvastatin tolerability. Ann Intern Med 2008;149:286-287.

- 112 Chow HH, Hakim IA, Vining DR, Crowell JA, Cordova CA, Chew WM, Xu MJ, Hsu $\mathrm{CH}$, Ranger-Moore J, Alberts D: Effects of repeated green tea catechin administration on human cytochrome P450 activity. Cancer Epidemiol Biomarkers Prev 2006;15: 2473-2476.

113 Donovan JL, Chavin KD, Devane CL, Taylor RM, Wang JS, Ruan Y, Markowitz JS: Green tea (Camellia sinensis) extract does not alter cytochrome p450 3A4 or 2D6 activity in healthy volunteers. Drug Metab Dispos 2004;32:906-908.

114 Anke J, Ramzan I: Pharmacokinetic and pharmacodynamic drug interactions with Kava (Piper methysticum Forst. f.). J Ethnopharmacol 2004;93:153-160.

Almeida JC, Grimsley EW: Coma from the health food store: interaction between kava and alprazolam. Ann Intern Med 1996;125: 940-941.

116 Schelosky L, Raffauf C, Jendroska K, Poewe $\mathrm{W}$ : Kava and dopamine antagonism. J Neurol Neurosurg Psychiatry 1995;58:639-640.

117 Rubin D, McGovern B, Kopelman RI: Back to basics. Am J Med 2006;119:482-483.

118 Shon JH, Park JY, Kim MS. Cha IJ, Chun BH, Shin JG: Effect of licorice (radix glycyrrhizae) on the pharmacokinetics and pharmacodynamics of midazolam in healthy subjects. Clin Pharmacol Ther 2001;69:P78.

119 Li HY, Xu W, Su J, Zhang X, Hu LW, Zhang WD: In vitro and in vivo inhibitory effects of glycyrrhetinic acid on cytochrome P450 3A activity. Pharmacology 2010;86:287-292.

- $120 \mathrm{Tu}$ JH, Hu DL, Dai LL, Sun Y, Fan L, Zhang M, Tan ZR, Chen Y, Li Z, Zhou HH: Effect of glycyrrhizin on CYP2C19 and CYP3A4 activity in healthy volunteers with different CYP2C19 genotypes. Xenobiotica 2010;40: 393-399.

121 Homma M, Oka K, Ikeshima K, Takahashi N, Niitsuma T, Fukuda T, Itoh H: Different effects of traditional Chinese medicines containing similar herbal constituents on prednisolone pharmacokinetics. J Pharm Pharmacol 1995;47:687-692.

122 Chen MF, Shimada F, Kato H, Yano S, Kanaoka M: Effect of oral administration of glycyrrhizin on the pharmacokinetics of prednisolone. Endocrinol Jpn 1991;38:167-174.

123 Rajnarayana K, Reddy MS, Vidyasagar J, Krishna DR: Study on the influence of silymarin pretreatment on metabolism and disposition of metronidazole. Arzneimittelforschung 2004;54:109-113.

124 Mills E, Wilson K, Clarke M, Foster B, Walker S, Rachlis B, DeGroot N, Montori VM, Gold W, Phillips E, Myers S, Gallicano K: Milk thistle and indinavir: a randomized controlled pharmacokinetics study and metaanalysis. Eur J Clin Pharmacol 2005;61:1-7.

125 DiCenzo R, Shelton M, Jordan K, Koval C, Forrest A, Reichman R, Morse G: Coadministration of milk thistle and indinavir in healthy subjects. Pharmacotherapy 2003;23:866-870.

126 Piscitelli SC, Formentini E, Burstein AH, Alfaro R, Jagannatha S, Falloon J: Effect of milk thistle on the pharmacokinetics of indinavir in healthy volunteers. Pharmacotherapy 2002;22:551-556.

127 Leber HW, Knauff S: Influence of silymarin on drug metabolising enzymes in rat and man. Arzneimittelforschung 1976;26: 1603-1605.

128 Fuhr U, Beckmann-Knopp S, Jetter A, Lück $\mathrm{H}$, Mengs $\mathrm{U}$ : The effect of silymarin on oral nifedipine pharmacokinetics. Planta Med 2007;73:1429-1435

129 van Erp NP, Baker SD, Zhao M, Rudek MA, Guchelaar HJ, Nortier JW, Sparreboom A, Gelderblom H: Effect of milk thistle (Silybum marianum) on the pharmacokinetics of irinotecan. Clin Cancer Res 2005;11: 7800-7806. 
130 Deng JW, Shon JH, Shin HJ, Park SJ, Yeo CW, Zhou HH, Song IS, Shin JG: Effect of silymarin supplement on the pharmacokinetics of rosuvastatin. Pharm Res 2008;25: 1807-1814.

-131 Dresser GK, Wacher V, Wong S, Wong HT, Bailey DG: Evaluation of peppermint oil and ascorbyl palmitate as inhibitors of cytochrome P4503A4 activity in vitro and in vivo. Clin Pharmacol Ther 2002;72:247255.

132 Prasad GV, Wong T, Meliton G, Bhaloo S: Rhabdomyolysis due to red yeast rice (Monascus purpureus) in a renal transplant recipient. Transplantation 2002;74:12001201.

133 Kuncl RW: Agents and mechanisms of toxic myopathy. Curr Opin Neurol 2009;22: 506-515.

-134 Markowitz JS, Donovan JL, Devane CL, Taylor RM, Ruan Y, Wang JS, Chavin KD: Multiple doses of saw palmetto (Serenoa repens) did not alter cytochrome P450 2D6 and 3A4 activity in normal volunteers. Clin Pharmacol Ther 2003;74:536-542.

135 Yue QY, Jansson K: Herbal drug curbicin and anticoagulant effect with and without warfarin: possibly related to the vitamin $\mathrm{E}$ component. J Am Geriatr Soc 2001;49: 838.

136 Corrigan JJ Jr, Marcus FI: Coagulopathy associated with vitamin E ingestion. JAMA 1974;230:1300-1301.

$\checkmark 137$ Lu Y, Chen DF: Analysis of Schisandra chinensis and Schisandra sphenanthera. J Chromatogr A 2009;1216:1980-1990.

138 Jiang W, Wang X, Xu X, Kong L: Effect of Schisandra sphenanthera extract on the concentration of tacrolimus in the blood of liver transplant patients. Int J Clin Pharmacol Ther 2010;48:224-229.

139 Xin HW, Wu XC, Li Q, Yu AR, Zhu M, Shen Y, Su D, Xiong L: Effects of Schisandra sphenanthera extract on the pharmacokinetics of tacrolimus in healthy volunteers. Br J Clin Pharmacol 2007;64:469-475.

140 Xin HW, Wu XC, Li Q, Yu AR, Xiong L: Effects of Schisandra sphenanthera extract on the pharmacokinetics of midazolam in healthy volunteers. Br J Clin Pharmacol 2009;67:541-546.

141 Cambria-Kiely JA: Effect of soy milk on warfarin efficacy. Ann Pharmacother 2002; 36:1893-1896.

142 Wang G, Xiao CQ, Li Z, Guo D, Chen Y, Fan L, Qian RH, Peng XJ, Hu DL, Zhou HH: Effect of soy extract administration on losartan pharmacokinetics in healthy female volunteers. Ann Pharmacother 2009;43: 1045-1049.

143 Borrelli F, Izzo AA: Herb-drug interactions with St John's wort (Hypericum perforatum): an update on clinical observations. AAPS J 2009;11:710-727.

- 144 Markowitz JS, Donovan JL, DeVane CL, Taylor RM, Ruan Y, Wang JS, Chavin KD: Effect of St John's wort on drug metabolism by induction of cytochrome P450 3A4 enzyme. JAMA 2003;290:1500-1504.

145 Arold G, Donath F, Maurer A, Diefenbach K, Bauer S, Henneicke-von Zepelin $\mathrm{HH}$, Friede M, Roots I: No relevant interaction with alprazolam, caffeine, tolbutamide, and digoxin by treatment with a low-hyperforin St John's wort extract. Planta Med 2005;71:331-337.

146 Wang Z, Gorski JC, Hamman MA, Huang SM, Lesko LJ, Hall SD: The effects of St John's wort (Hypericum perforatum) on human cytochrome P450 activity. Clin Pharmacol Ther 2001;70:317-326.

147 Wang LS, Zhu B, Abd El-Aty AM, Zhou G, Li Z, Wu J, Chen GL, Liu J, Tang ZR, An W, Li Q, Wang D, Zhou HH: The influence of St John's Wort on CYP2C19 activity with respect to genotype. J Clin Pharmacol 2004; 44:577-581.

148 Wenk M, Todesco L, Krähenbühl S: Effect of St John's wort on the activities of CYP1A2, CYP3A4, CYP2D6, N-acetyltransferase 2, and xanthine oxidase in healthy males and females. Br J Clin Pharmacol 2004;57:495-499.

149 Dresser GK, Schwarz UI, Wilkinson GR, Kim RB: Coordinate induction of both cytochrome P4503A and MDR1 by St John's wort in healthy subjects. Clin Pharmacol Ther 2003;73:41-50.

150 Roby CA, Dryer DA, Burstein AH: St John's wort: effect on CYP2D6 activity using dextromethorphan-dextrorphan ratios. J Clin Psychopharmacol 2001;21:530-532.

151 Xie R, Tan LH, Polasek EC, Hong C, TeillolFoo M, Gordi T, Sharma A, Nickens DJ, Arakawa T, Knuth DW, Antal EJ: CYP3A and P-glycoprotein activity induction with St John's Wort in healthy volunteers from 6 ethnic populations. J Clin Pharmacol 2005; 45:352-356.

152 Mueller SC, Majcher-Peszynska J, Mundkowski RG, Uehleke B, Klammt S, Sievers H, Lehnfeld R, Frank B, Thurow K, Kundt G, Drewelow B: No clinically relevant CYP3A induction after St John's wort with low hyperforin content in healthy volunteers. Eur J Clin Pharmacol 2009;65:81-87.

153 Wang XD, Li JL, Su QB, Guan S, Chen J, Du J, He YW, Zeng J, Zhang JX, Chen X, Huang M, Zhou SF: Impact of the haplotypes of the human pregnane $\mathrm{X}$ receptor gene on the basal and St John's wort-induced activity of cytochrome P450 3A4 enzyme. Br J Clin Pharmacol 2009;67:255-261.

154 Wang LS, Zhou G, Zhu B, Wu J, Wang JG, Abd El-Aty AM, Li T, Liu J, Yang TL, Wang D, Zhong XY, Zhou HH: St John's wort induces both cytochrome P450 3A4-catalyzed sulfoxidation and 2C19-dependent hydroxylation of omeprazole. Clin Pharmacol Ther 2004;75:191-197.

155 Hafner V, Jäger M, Matthée AK, Ding R, Burhenne J, Haefeli WE, Mikus G: Effect of simultaneous induction and inhibition of CYP3A by St John's Wort and ritonavir on
CYP3A activity. Clin Pharmacol Ther 2010; 87:191-196.

156 Wang XD, Li JL, Su QB, Guan S, Chen J, Du J, He YW, Zeng J, Zhang JX, Chen X, Huang M, Zhou SF: Impact of the haplotypes of the human pregnane $\mathrm{X}$ receptor gene on the basal and St John's wort-induced activity of cytochrome P450 3A4 enzyme. Br J Clin Pharmacol 2009;67:255-261.

157 Imai H, Kotegawa T, Tsutsumi K, Morimoto T, Eshima N, Nakano S, Ohashi K: The recovery time-course of CYP3A after induction by St John's wort administration. Br J Clin Pharmacol 2008;65:701-707.

158 Mai I, Bauer S, Perloff ES, Johne A, Uehleke B, Frank B, Budde K, Roots I: Hyperforin content determines the magnitude of the St John's wort-cyclosporine drug interaction. Clin Pharmacol Ther 2004;76:330-340.

-159 Hall SD, Wang Z, Huang SM, Hamman MA, Vasavada N, Adigun AQ, Hilligoss JK, Miller M, Gorski JC: The interaction between St John's wort and an oral contraceptive. Clin Pharmacol Ther 2003;74:525535.

160 Mueller SC, Majcher-Peszynska J, Uehleke B, Klammt S, Mundkowski RG, Miekisch W, Sievers H, Bauer S, Frank B, Kundt G, Drewelow B: The extent of induction of CYP3A by St. John's wort varies among products and is linked to hyperforin dose. Eur J Clin Pharmacol 2006;62:29-36.

161 Mueller SC, Majcher-Peszynska J, Mundkowski RG, Uehleke B, Klammt S, Sievers H, Lehnfeld R, Frank B, Thurow K, Kundt G, Drewelow B: No clinically relevant CYP3A induction after St. John's wort with low hyperforin content in healthy volunteers. Eur J Clin Pharmacol 2009;65:81-87.

162 Bon S, Hartmann K, Kubn M: Johanniskraut: ein Enzyminduktor? Schweiz Apoth Ztg 1999;16:535-536.

163 Breidenbach T, Kliem V, Burg M, Radermacher J, Hoffmann MW, Klempnauer J: Profound drop of cyclosporin A whole blood trough levels caused by St. John's wort (Hypericum perforatum). Transplantation 2000;69:2229-2230.

164 Breidenbach T, Hoffmann MW, Becker T, Schlitt H, Klempnauer J: Drug interaction of St John's wort with cyclosporin. Lancet 2000;355:1912.

165 Roots I, Johne A, Mauer A: ArzneimittelInteraktionen von Hypericum-Extract. Proc Germ Soc Pharmacol, Berlin, June 2000.

166 Rey JM, Walter G: Hypericum perforatum (St John's wort) in depression: pest or blessing? Med J Aust 1998;169:583-586.

167 Ruschitzka F, Meier PJ, Turina M, Lüscher TF, Noll G: Acute heart transplant rejection due to Saint John's wort. Lancet 2000;355: 548-549.

168 Barone GW, Gurley BJ, Ketel BL, Lightfoot ML, Abul-Ezz SR: Drug interaction between St John's wort and cyclosporine. Ann Pharmacother 2000;34:1013-1016. 
-169 Mai I, Krüger H, Budde K, Johne A, Brockmöller J, Neumayer HH, Roots I: Hazardous pharmacokinetic interaction of Saint John's wort (Hypericum perforatum) with the immunosuppressant cyclosporin. Int J Clin Pharmacol Ther 2000;38:500-502.

170 Karliova M, Treichel U, Malagò M, Frilling A, Gerken G, Broelsch CE: Interaction of Hypericum perforatum (St. John's wort) with cyclosporin A metabolism in a patient after liver transplantation. J Hepatol 2000; 33:853-855.

-171 Mandelbaum A, Pertzborn F, MartinFacklam M, Wiesel M: Unexplained decrease of cyclosporin trough levels in a compliant renal transplant patient. Nephrol Dial Transplant 2000;15:1473-1474.

172 Turton-Weeks SM, Barone GW, Gurley BJ, Ketel BL, Lightfoot ML, Abul-Ezz SR: St John's wort: a hidden risk for transplant patients. Prog Transplant 2001;11:116120.

173 Ahmed SM, Banner NR, Dubrey SW: Low cyclosporin-A level due to Saint-John'swort in heart transplant patients. J Heart Lung Transplant 2001;20:795.

174 Beer AM, Ostermann T: St. John's wort: interaction with cyclosporine increases risk of rejection for the kidney transplant and raises daily cost of medication (in German). Med Klin (Munich) 2001;96:480-483.

- 175 Moschella C, Jaber BL: Interaction between cyclosporine and Hypericum perforatum (St John's wort) after organ transplantation. Am J Kidney Dis 2001;38:1105-1107.

- 176 Alscher DM, Klotz U: Drug interaction of herbal tea containing St John's wort with cyclosporine. Transpl Int 2003;16:543544.

$\checkmark 177$ Hebert MF, Park JM, Chen YL, Akhtar S, Larson AM: Effects of St John's wort (Hypericum perforatum) on tacrolimus pharmacokinetics in healthy volunteers. J Clin Pharmacol 2004;44:89-94.

178 Mai I, Störmer E, Bauer S, Krüger H, Budde K, Roots I: Impact of St John's wort treatment on the pharmacokinetics of tacrolimus and mycophenolic acid in renal transplant patients. Nephrol Dial Transplant 2003;18:819-822.

179 Saraga M, Zullino DF: St John's Wort, corticosteroids, cocaine, alcohol ... and a first manic episode (in French). Praxis (Bern 1994) 2005;94:987-989.

180 Bell EC, Ravis WR, Chan HM, Lin YJ: Lack of pharmacokinetic interaction between St John's wort and prednisone. Ann Pharmacother 2007;41:1819-1824.

181 Caraci F, Crupi R, Drago F, Spina E: Metabolic drug interactions between antidepressants and anticancer drugs: focus on selective serotonin reuptake inhibitors and hypericum extract. Curr Drug Metab 2011; 12:570-577.

182 Howland RH: Update on St John's Wort. J Psychosoc Nurs Ment Health Serv 2010;48: 20-24.
83 Pfrunder A, Schiesser M, Gerber S, Haschke M, Bitzer J, Drewe J: Interaction of St John's wort with low-dose oral contraceptive therapy: a randomized controlled trial. Br J Clin Pharmacol 2003;56:683-690.

184 Murphy PA, Kern SE, Stanczyk FZ, Westhoff CL: Interaction of St John's wort with oral contraceptives: effects on the pharmacokinetics of norethindrone and ethinyl estradiol, ovarian activity and breakthrough bleeding. Contraception 2005;71:402-408.

185 Will-Shahab L, Bauer S, Kunter U, Roots I, Brattström A: St John's wort extract (Ze 117) does not alter the pharmacokinetics of a low-dose oral contraceptive. Eur J Clin Pharmacol 2009;65:287-294.

186 Schwarz UI, Büschel B, Kirch W: Unwanted pregnancy on self-medication with St John's wort despite hormonal contraception. Br J Clin Pharmacol 2003;55:112-113.

187 Etogo-Asse F, Boemer F, Sempoux C, Geubel A: Acute hepatitis with prolonged cholestasis and disappearance of interlobular bile ducts following tibolone and Hypericum perforatum (St John's wort). Case of drug interaction? Acta Gastroenterol Belg 2008;71:36-38.

188 Wang PH, Cheng MH, Chao HT, Chao KC: Effects of tibolone on the breast of postmenopausal women. Taiwan J Obstet Gynecol 2007;46:121-126

189 Maurer A, Johne A, Bauer S, Brockmöller J, Donath F, Roots I, Langheinrich M, Hübner WD: Interaction of St John's wort extract with phenprocoumon. Eur J Clin Pharmacol 1999;55:A22.

190 Johne A, Brockmöller J, Bauer S, Maurer A, Langheinrich M, Roots I: Pharmacokinetic interaction of digoxin with an herbal extract from St John's wort (Hypericum perforatum). Clin Pharmacol Ther 1999;66:338345.

191 Mueller SC, Uehleke B, Woehling H, Petzsch M, Majcher-Peszynska J, Hehl EM, Sievers H, Frank B, Riethling AK, Drewelow B: Effect of St John's wort dose and preparations on the pharmacokinetics of digoxin. Clin Pharmacol Ther 2004;75:546-557.

192 Sugimoto K, Ohmori M, Tsuruoka S, Nishiki K, Kawaguchi A, Harada K, Arakawa M, Sakamoto K, Masada M, Miyamori I, Fujimura A: Different effects of St John's wort on the pharmacokinetics of simvastatin and pravastatin. Clin Pharmacol Ther 2001;70:518-524.

193 Andrén L, Andreasson A, Eggertsen R: Interaction between a commercially available St John's wort product (Movina) and atorvastatin in patients with hypercholesterolemia. Eur J Clin Pharmacol 2007;63:913916.

194 Gordon RY, Becker DJ, Rader DJ: Reduced efficacy of rosuvastatin by St John's wort. Am J Med 2009;122:e1-e2.

- 195 Portolés A, Terleira A, Calvo A, Martínez I, Resplandy G: Effects of Hypericum Perfora- tum on ivabradine pharmacokinetics in healthy volunteers: an open-label, pharmacokinetic interaction clinical trial. J Clin Pharmacol 2006;46:1188-1194.

196 Tannergren C, Engman H, Knutson L, Hedeland $\mathrm{M}$, Bondesson $\mathrm{U}$, Lennernäs $\mathrm{H}$ : St John's wort decreases the bioavailability of $\mathrm{R}$ - and S-verapamil through induction of the first-pass metabolism. Clin Pharmacol Ther 2004;75:298-309.

197 Schwarz UI, Hanso H, Oertel R, Miehlke S, Kuhlisch E, Glaeser H, Hitzl M, Dresser GK, Kim RB, Kirch W: Induction of intestinal P-glycoprotein by St John's wort reduces the oral bioavailability of talinolol. Clin Pharmacol Ther 2007;81:669-678.

198 Piscitelli SC, Burstein AH, Chaitt D, Alfaro RM, Falloon J: Indinavir concentrations and St John's wort. Lancet 2000;355:547548.

199 de Maat MM, Hoetelmans RM, Math t RA, van Gorp EC, Meenhorst PL, Mulder JW, Beijnen JH: Drug interaction between St John's wort and nevirapine. AIDS 2001;15: 420-421.

200 Mathijssen RH, Verweij J, de Bruijn P, Loos WJ, Sparreboom A: Effects of St John's wort on irinotecan metabolism. J Natl Cancer Inst 2002;94:1247-1249.

201 Frye RF, Fitzgerald SM, Lagattuta TF, Hruska MW, Egorin MJ: Effect of St John's wort on imatinib mesylate pharmacokinetics. Clin Pharmacol Ther 2004;76:323-329.

202 Smith P, Bullock JM, Booker BM, Haas CE, Berenson CS, Jusko WJ: The influence of St John's wort on the pharmacokinetics and protein binding of imatinib mesylate. Pharmacotherapy 2004;24:1508-1514.

203 Kawaguchi A, Ohmori M, Tsuruoka S, Nishiki K, Harada K, Miyamori I, Yano R, Nakamura T, Masada M, Fujimura A: Drug interaction between St John's Wort and quazepam. Br J Clin Pharmacol 2004;58 403-410.

204 Hojo Y, Echizenya M, Ohkubo T, Shimizu T: Drug interaction between St John's wort and zolpidem in healthy subjects. J Clin Pharm Ther 2011;36:711-715.

205 Dannawi M: Possible serotonin syndrome after combination of buspirone and St John's Wort. J Psychopharmacol 2002;16: 401.

206 Lantz MS, Buchalter E, Giambanco V: St John's wort and antidepressant drug interactions in the elderly. J Geriatr Psychiatry Neurol 1999;12:7-10.

207 Gordon JB: SSRIs and St John's wort: possible toxicity? Am Fam Physician 1998;57: 950.

208 Bryant SM, Kolodchak J: Serotonin syndrome resulting from an herbal detox cocktail. Am J Emerg Med 2004;22:625-626.

209 Barbenel DM, Yusufi B, O'Shea D, Bench CJ: Mania in a patient receiving testosterone replacement postorchidectomy taking St John's wort and sertraline. J Psychopharmacol 2000;14:84-86. 
-210 Johne A, Schmider J, Brockmöller J, Stadelmann AM, Störmer E, Bauer S, Scholler G, Langheinrich M, Roots I: Decreased plasma levels of amitriptyline and its metabolites on comedication with an extract from $\mathrm{St}$ John's wort (Hypericum perforatum). J Clin Psychopharmacol 2002;22:46-54.

211 Crowe S, McKeating K: Delayed emergence and St John's wort. Anesthesiology 2002;96: 1025-1027.

212 Irefin S, Sprung J: A possible cause of cardiovascular collapse during anesthesia: long-term use of St John's Wort. J Clin Anesth 2000;12:498-499.

-213 Rengelshausen J, Banfield M, Riedel KD, Burhenne J, Weiss J, Thomsen T, WalterSack I, Haefeli WE, Mikus G: Opposite effects of short-term and long-term St John's wort intake on voriconazole pharmacokinetics. Clin Pharmacol Ther 2005;78:2533.

-214 Burstein AH, Horton RL, Dunn T, Alfaro RM, Piscitelli SC, Theodore W: Lack of effect of St John's Wort on carbamazepine pharmacokinetics in healthy volunteers. Clin Pharmacol Ther 2000;68:605-612.

215 Kerr BM, Thummel KE, Wurden CJ, Klein SM, Kroetz DL, Gonzalez FJ, Levy RH: Human liver carbamazepine metabolism. Role of CYP3A4 and CYP2C8 in 10,11-epoxide formation. Biochem Pharmacol 1994;47: 1969-1979.

-216 Eich-Höchli D, Oppliger R, Golay KP, Baumann P, Eap CB: Methadone maintenance treatment and St John's Wort - a case report. Pharmacopsychiatry 2003;36:35-37.

-217 Milton JC, Abdulla A: Prolonged oro-facial dystonia in a 58 year old female following therapy with bupropion and St John's wort. Br J Clin Pharmacol 2007;64:717-718.

-218 Lei HP, Yu XY, Xie HT, Li HH, Fan L, Dai LL, Chen Y, Zhou HH: Effect of St John's wort supplementation on the pharmacokinetics of bupropion in healthy male Chinese volunteers. Xenobiotica 2010;40:275281.

-219 Nebel A, Schneider BJ, Baker RK, Kroll DJ: Potential metabolic interaction between St John's wort and theophylline. Ann Pharmacother 1999;33:502.

-220 Morimoto T, Kotegawa T, Tsutsumi K, Ohtani Y, Imai H, Nakano S: Effect of St John's wort on the pharmacokinetics of theophylline in healthy volunteers. J Clin Pharmacol 2004;44:95-101.

-221 Bonetto N, Santelli L, Battistin L, Cagnin A: Serotonin syndrome and rhabdomyolysis induced by concomitant use of triptans, fluoxetine and hypericum. Cephalalgia 2007;27:1421-1423.
222 Carrasco MC, Vallejo JR, Pardo-de-Santayana M, Peral D, Martín MA, Altimiras J: Interactions of Valeriana officinalis L. and Passiflora incarnata L. in a patient treated with lorazepam. Phytother Res 2009;23: 1795-1796.

223 Khawaja IS, Marotta RF, Lippmann S: Herbal medicines as a factor in delirium. Psychiatr Serv 1999;50:969-970.

224 Deahl M: Betel nut-induced extrapyramidal syndrome: an unusual drug interaction. Mov Disord 1989;4:330-332.

225 Ohkawa S, Yoneda Y, Ohsumi Y, Tabuchi M: Warfarin therapy and chlorella (in Japanese). Rinsho Shinkeigaku 1995;35:806807.

226 Lambert JP, Cormier J: Potential interaction between warfarin and boldo-fenugreek. Pharmacotherapy 2001;21:509-512.

227 Holman CP, Bell AFJ: A trial of evening primrose oil in the treatment of chronic schizophrenia. J Orthomol Psychiatry 1983;12:302-304

228 Hanselin MR, Vande Griend JP, Linnebur SA: INR elevation with maitake extract in combination with warfarin. Ann Pharmacother 2010;44:223-224.

229 Gutsch J: On the state of therapy of chronic myeloid leukemia in adults with the mistletoe preparation Helixor (in German). Ärztezeitschrift für Naturheilverfahren 1982; 23:523-544.

230 Sobieraj DM, Freyer CW: Probable hypoglycemic adverse drug reaction associated with prickly pear cactus, glipizide, and metformin in a patient with type 2 diabetes mellitus. Ann Pharmacother 2010;44: 1334-1337.

231 Leung H, Hung A, Hui AC, Chan TY: Warfarin overdose due to the possible effects of Lycium barbarum L. Food Chem Toxicol 2008;46:1860-1862.

232 Lam AY, Elmer GW, Mohutsky MA: Possible interaction between warfarin and $L y$ cium barbarum L. Ann Pharmacother 2001; 35:1199-1201.

233 Mahmoud BM, Ali HM, Homeida MM, Bennett JL: Significant reduction in chloroquine bioavailability following coadministration with the Sudanese beverages Aradaib, Karkadi and Lemon. J Antimicrob Chemother 1994;33:1005-1009.

234 Kolawole JA, Maduenyi A: Effect of zobo drink (Hibiscus sabdariffa water extract) on the pharmacokinetics of acetaminophen in human volunteers. Eur J Drug Metab Pharmacokinet 2004;29:25-29.

235 Richter WO, Jacob BG, Schwandt P: Interaction between fibre and lovastatin. Lancet 1991;338:706.

236 Gin H, Orgerie MB, Aubertin J: The influence of Guar gum on absorption of metformin from the gut in healthy volunteers. Horm Metab Res 1989;21:81-83.
237 Eltayeb IB, Awad AI, Elderbi MA, Shadad SA: Effect of gum arabic on the absorption of a single oral dose of amoxicillin in healthy Sudanese volunteers. J Antimicrob Chemother 2004;54:577-578.

238 Dalvi SS, Nayak VK, Pohujani SM, Desai NK, Kshirsagar NA, Gupta KC: Effect of gugulipid on bioavailability of diltiazem and propranolol. J Assoc Physicians India 1994;42:454-455.

239 Huupponen R, Seppälä P, Iisalo E: Effect of guar gum, a fibre preparation, on digoxin and penicillin absorption in man. Eur J Clin Pharmacol 1984;26:279-281.

240 Al Faraj S: Antagonism of the anticoagulant effect of warfarin caused by the use of Commiphora molmol as a herbal medication: a case report. Ann Trop Med Parasitol 2005; 99:219-220

241 Tankanow R, Tamer HR, Streetman DS, Smith SG, Welton JL, Annesley T, Aaronson $\mathrm{KD}$, Bleske BE: Interaction study between digoxin and a preparation of hawthorn (Crataegus oxyacantha). J Clin Pharmacol 2003;43:637-642.

242 De Smet PA, Floor-Schreudering A, Bouvy ML, Wensing M: Clinical risk management of interactions between natural products and drugs. Curr Drug Metab 2008;9:10551062.

243 González-Stuart A: Herbal product use by older adults. Maturitas 2011;68:52-55.

244 Ueng YF, Chen CC, Tsai CC, Soucek P: Differential inductive profiles of hepatic cytochrome P450s by the extracts of Sophora flavescens in male and female C57BL/6JNarl mice. J Ethnopharmacol 2009; 126:437446.

245 Bush TM, Rayburn KS, Holloway SW, Sanchez-Yamamoto DS, Allen BL, Lam T, So BK, Tran de H, Greyber ER, Kantor S, Roth LW: Adverse interactions between herbal and dietary substances and prescription medications: a clinical survey. Altern Ther Health Med 2007;13:30-35.

246 Harrigan JT: Patient disclosure of the use of complementary and alternative medicine to their obstetrician/gynaecologist. J Obstet Gynaecol 2011;31:59-61.

247 Wanwimolruk S, Wong K, Wanwimolruk P: Variable inhibitory effect of different brands of commercial herbal supplements on human cytochrome P-450 CYP3A4. Drug Metabol Drug Interact 2009;24:1735.

248 Capasso R, Izzo AA, Pinto L, Bifulco T, Vitobello C, Mascolo N: Phytotherapy and quality of herbal medicines. Fitoterapia 2000;71(suppl 1):S58-S65.

249 King AR, Russett FS, Generali JA, Grauer DW: Evaluation and implications of natural product use in preoperative patients: a retrospective review. $\mathrm{BMC}$ Complement $\mathrm{Al}$ tern Med 2009;9:38. 